\title{
Fluoride contamination in groundwater sources in Southwestern Nigeria: Assessment using multivariate statistical approach and human health risk
}

\section{Order of Authors}

1. Emenike Chidozie PraiseGod* (praisegod.emenike@covenantuniversity.edu.ng)

${ }^{1}$ Department of Civil Engineering, Covenant University, Ota, Ogun State, Nigeria

${ }^{2}$ Cranfield Water Science Institute, School of Water, Energy and Environment, Cranfield University, Bedfordshire, United Kingdom.

*(Corresponding author)

2. Tenebe Imokhai Theophilus (imokhai.tenebe@covenantuniversity.edu.ng)

${ }^{1}$ Department of Civil Engineering, Covenant University, Ota, Ogun State, Nigeria.

3. Peter Jarvis (p.jarvis@cranfield.ac.uk)

Professor of Water Science \& Technology

${ }^{2}$ Cranfield Water Science Institute, School of Water, Energy and Environment, Cranfield University, Bedfordshire, United Kingdom. 

21 issues. Nigeria.

\section{Fluoride contamination in groundwater sources in Southwestern Nigeria: Assessment using multivariate statistical approach and human health risk}

\section{Abstract}

The present study investigated the ionic and fluoride concentrations in tap water and its associated health risk to local dwellers of Ogun State (Abeokuta south), Nigeria. 63 samples were collected from twenty-one different locations. Results obtained revealed the mean concentration of fluoride $\left(\mathrm{F}^{-}\right)$as $1.23 \mathrm{mg} / \mathrm{L}$. Other water quality parameters such as total dissolved solids (TDS), electrical conductivity (EC), $\mathrm{Fe}^{2+}$, and $\mathrm{SO}_{4}{ }^{2-}$ surpassed the WHO limits for drinking water quality. Strong positive correlation was observed between $\mathrm{F}^{-}$and TDS; $\mathrm{F}^{-}$and $\mathrm{pH}$; TDS and EC; TDS and $\mathrm{Mg}^{2+}$; TDS and $\mathrm{SO}_{4}{ }^{2-}$; TDS and $\mathrm{HCO}_{3}{ }^{-} ; \mathrm{EC}$ and $\mathrm{HCO}_{3}{ }^{-} ; \mathrm{EC}$ and $\mathrm{SO}_{4}{ }^{2-} ; \mathrm{Na}^{+}$and $\mathrm{Cl}^{-} ; \mathrm{SO}_{4}{ }^{2-}$ and $\mathrm{Cl}^{-}$. In addition, Empirical Bayesian Kriging (EBK) model was employed to spatially distribute the concentration of the analyzed elements within the study region. The chronic daily dose $(C D D)$ and hazard quotient $(\mathrm{HQ})$ were also used to evaluate the health risk associated with $\mathrm{F}^{-}$, considering dermal and ingestion as pathways. The results revealed that the associated HQ for infants between the age range of 6-12 months within about $91 \%$ of the study region surpassed the accepted $H Q$ limit. However, the HQ for age categories 11-16 years; > 65years; 18-21years; $\geq 21$ years; 1618years within $95.2 \%, 90.5 \%, 80.95 \%$ and $100 \%$ of the study location were less than 1 . Conclusively, the $H Q$ values obtained in this study should serve as a baseline information for water management authorities, policymakers and the society at large towards addressing these pollution

Keywords: Risk assessment; Abeokuta; Pollution; Groundwater; Dispersion; Southwestern 


\section{Introduction}

26 The presence of fluoride at elevated concentrations in drinking water has caused severe health

27 effects in humans in some parts of the world (Bhatnagar et al., 2011; Shen and Schäfer, 2015).

28 Fluorine exists in the environment through combination with other elements to form highly soluble

29 fluoride compounds. The main source of fluorine in water is from natural deposition from geogenic

30 sources in aquifers (EPA, 2010; Sun et al., 2013). The primary way by which humans ingest

31 fluoride is through consumption of contaminated groundwater (Singh et al., 2013; Singh and

32 Mukherjee, 2015; Subba Rao et al., 2013). The World Health Organization (WHO) recommended

33 the concentration of fluoride that can cause minimal health risk to be $1.5 \mathrm{mg} / \mathrm{L}$. However, more

34 than 200 million people living across 20 developing and developed countries regularly consume

35 water with elevated fluoride concentrations above the standard guidelines set by the WHO (Amini

36 et al., 2008; Fawell et al., 2006; Shen and Schäfer, 2015). Some countries such as Tanzania in the

37 East of Africa have a drinking water standard for fluoride of $4 \mathrm{mg} / \mathrm{l}$, well above the WHO

38 recommended value. This can cause a number of possible health problems, including dental and

39 skeletal fluorosis. In the Rift Valley, East Africa, more than 80 million people display a range of

40 symptoms consistent with dental fluorosis (Shen and Schäfer, 2015; Smedley et al., 2002).

41 However, this should also be placed in the context of water scarcity, population growth and access

42 to clean water in the region.

High concentrations of fluoride in humans can lead to various health problems such as nervous

44 system damage (Kaoud and Kalifa, 2010), reduced fertility (Izquierdo-Vega et al., 2008),

45 intellectual impairment in children (Ding et al., 2011; Shivaprakash et al., 2011), urinary tract

46 disease (Jha et al., 2011), as well as dental and skeletal fluorosis in children and adults (Maguire, 
47 2014). In turn, this can lead to significant lower back pains (Namkaew and Wiwatanadate, 2012).

48 It has been proposed that regularly consuming water with fluoride concentrations of at least 0.9

$49 \mathrm{mg} / \mathrm{l}$ is the cause of at least $37 \%$ of dental fluorosis cases (McGrady et al., 2012). Levy and Leclerc,

50 (2012) also correlated fluoride in drinking water with bone diseases (Osteosarcoma) in adolescents

51 and children. Sun et al., (2013) discovered that cases of hypertension in adults could be linked to

52 fluoride present in drinking water. They further emphasized that fluoride exposure could cause an

53 increase in plasma Endothelin-1 (ET-1) levels. Liu et al., (2014) also identified a link between

54 fluoride exposure from drinking water and carotid artery atherosclerosis in adults. In a recent study

55 conducted by Irigoyen-Camacho et al. (2016), reports showed that increased morbidity and

56 mortality rate could be correlated with nutritional deficiencies propagated by fluoride intake. It

57 should be noted that at low concentrations, ingesting fluoride from drinking water can hinder

58 dental caries and some health authorities deliberately add fluoride to drinking water to reduce the

59 incidence of enamel decay (Freire et al., 2016).

60 In the urban regions of Nigeria, the wholescale provision of reliable access to drinking water has

61 been made difficult due to increasing population and habitation spread within cities (Emenike et

62 al., 2016; Odjegba et al., 2015, 2014), a similar case as seen in Tanzania. Many localities in

63 southwestern Nigeria and Tanzania, in these regions, are supplied with surface water for their

64 source of drinking water (Adekunle et al., 2013). However, in many cases, these surface waters

65 are heavily contaminated and polluted, particularly with respect to the microbial quality of the

66 water, and are subsequently poorly treated making this water unfit for human consumption (John-

67 Dewole, 2012; Tenebe et al., 2017, 2016). For this reason, many people have accessed

68 groundwater for their drinking water given its perceived higher quality (Adekunle et al., 2013).

69 However, given the noted pollution of such groundwater systems with fluoride and the evidenced 
70 adverse effect on human health, a stronger link between fluoride concentration and its health

71 impacts is needed to enable more thorough risk assessment and mitigation measures to be applied.

72 Recently, researchers have adopted the human health risk assessment (HHRA) model to determine

73 the adverse effect of absorbing or ingesting chemicals at a range of concentrations (Yang et al.,

74 2012; Zhai et al., 2017). Therefore, this study seeks to consider two common pathways (ingestion

75 and dermal) by which human populations can be exposed to high fluoride concentrations. In the

76 same vein, the study capitalizes on the risk assessment indicators endorsed by the US EPA (2011)

77 to assess the extent of fluoride contamination in groundwater and evaluate in detail, the health risk

78 associated with fluoride pollution in groundwater. In furtherance of this, reports of elevated

79 fluoride concentration in drinking water and its potential health risk has been investigated in

80 Tunisia (Guissouma et al., 2017), Iran (Battaleb-Looie et al., 2013; Dehbandi et al., 2018; Yousefi

81 et al., 2018), Ghana (Craig et al., 2015; Salifu et al., 2012), China (Zhang et al., 2017) and United

82 Arab Emirates (Walia et al., 2017). But, to the best of our knowledge, there are a dearth of

83 literatures in Nigeria with no previous investigation in the studied region in this regard. Therefore,

84 this study focuses on the following objectives. First, to determine the spatial distribution of fluoride

85 and other groundwater quality parameters in Abeokuta. Secondly, to analyze the interrelationship

86 between fluoride and other water quality parameters. Thirdly, adopt geostatistical modeling in

87 which semivariogram graphs will be used to describe and validate the extent of contamination via

88 the interpolation of known concentration from sampled locations. Finally, assess the health risks

89 associated with fluoride concentration in groundwater. To establish a more realistic base for

90 judgement, ingestion and dermal pathways were investigated. Also, the receptors (individuals)

91 were classified into seven age groups ( 6 - 12 months, 6 - 11 years, 11 - 16 years, 16 - 18 years,

$9218-21$ years, $\geq 21$ years and $>65$ years). This will assist in adding relevant data to local rural 
93 water management, policy and decision makers to take adequate measures in safeguarding the

94 lives of residents in endemic fluoride regions.

\section{Materials and Methods}

Study area

97 Abeokuta, the capital of Ogun state, occupies $40.6 \mathrm{~km}^{2}$ (latitude $7.17-7.25^{\circ} \mathrm{N}$; longitudes 3.28-

$\left.983.43^{\circ} \mathrm{E}\right)$. The population of Abeokuta is estimated to be 451,600 with an annual growth rate of 99 3.5\% (National Population Commission, 2010). The area sits on a complex geological system, 100 composed of a mix of rock from the Precambrian period. The complex spreads through the 101 southwestern region of Nigeria, sharing a part with the Dahomey basin composed of sedimentary 102 rock (Rahaman, 1976). The region is also linked to Lagos by river/canal (130 km) or by railway $103(77 \mathrm{~km})$ and shares common borders with Ibadan, Shagamu, Ilaro, Ketuo, and Iseyin. The sample 104 locations were targeted at regions with high population density.

“Fig. 1 is about here."

\section{Sample collection}

109 The water samples analyzed in this study were obtained from taps that were connected directly to 110 the underlying groundwater aquifer. In total, 63 water samples were collected from twenty-one 111 locations (Fig. 1) in the study area (R1 - R21). The sampled taps were regularly used by 112 householders mainly for consumption and domestic activities. At the point of collection, the taps 113 were allowed to run for about 15 min before representative samples were collected to reflect the 
114 status of the aquifer and the water consumed by the householder. Sample bottles (made of 115 polyethylene) were washed with distilled water (mixed with 20\% nitric acid) prior to sampling.

116 The sample bottles were further rinsed three times with distilled water to remove any trace of acid 117 and then air-dried before transporting to the sampling site. At the sampling location, the bottles 118 were rinsed three times with tap water prior to collection to ensure no acid interference. After 119 sample collection, the containers were sealed with screw corks, labeled appropriately, placed in a 120 container filled with ice and immediately transferred to a refrigerator regulated at $4{ }^{\circ} \mathrm{C}$.

121 As soon as each sample was collected, unstable and sensitive water quality parameters such as 122 total dissolved solids (TDS), electrical conductivity (EC), temperature (Temp.), alkalinity (Alka.) 123 and $\mathrm{pH}$ were measured in situ with a calibrated multiparameter probe (HANNA - HI2030 124 Salinity/TDS/EC meter and HANNA - HI98130). Standard analytical procedures (APHA, 2005) 125 were followed to measure the ionic concentration of major ions. Sodium $(\mathrm{Na}+)$, potassium $\left(\mathrm{K}^{+}\right)$, 126 magnesium $\left(\mathrm{Mg}^{2+}\right)$, calcium $\left(\mathrm{Ca}^{2+}\right)$, iron $\left(\mathrm{Fe}^{2+}\right)$ and manganese $(\mathrm{Mn})$ were measured using flame 127 photometric method (Flame Atomic Absorption Spectrophotometry), dissolved silica $\left(\mathrm{SiO}_{2}\right)$ by 128 molybdosilicate method with UV-Visible spectrometer and Nitrates $\left(\mathrm{NO}_{3}{ }^{-}\right)$concentration by UV129 Visible spectrometer. Sulfate $\left(\mathrm{SO}_{4}{ }^{2-}\right)$ concentration was determined by the turbidimetric method, 130 bicarbonate $\left(\mathrm{HCO}_{3}{ }^{-}\right)$, chloride $\left(\mathrm{Cl}^{-}\right)$, and carbonate $\left(\mathrm{CO}_{3}{ }^{2-}\right)$ concentration were measured by 131 volumetric method. A calibrated potentiometric ion-selection electrode (HANNA-HI5315) 132 attached to a water-resistant portable ORP/pH/ISE meter (HANNA-HI98191) was used to 133 measure the concentration of fluoride ion $\left(\mathrm{F}^{-}\right)$.

\section{Quality control}

135 Quality assurance was achieved through the implementation of standard laboratory procedures and 136 quality control techniques which included standardized calibration, replication, use of analytical 
137 grade reagent blanks and spikes, and following standard operating measures. Calibration of 138 multiparameter instruments was performed after collecting samples from a location. The samples 139 were analyzed in triplicate, and the mean value were recorded. During metal analysis, constant monitoring of reagent blanks was administered, and standard detection limits were maintained.

\section{Geostatistical modeling}

142 Water quality parameters were modelled spatially using the Empirical Bayesian Kriging (EBK)

143 model. The EBK model automatically transforms the complicated aspects of the Kriging model by 144 forming a restricted neighbor between a mapped property via interpolation. The interpolation relies 145 on the subpopulation of the available dataset to produce independent trends (Samsonova et al., 146 2017). One essential element that differentiates the EBK model from other Kriging models is the 147 ability to consider the uncertainties in semivariogram computation (Magesh et al., 2017). Thus, 148 the operational module of the EBK estimation is based on the exploitation of original data to 149 predict the semivariogram model (SVM) where a new set of data is generated at the original data 150 point. Furthermore, the freshly simulated data is used to predict the SVM. During the estimation 151 of the new SVM, predicted standard errors are processed at locations that had no observation,

152 producing several spectrums of SVM due to repeated operations from original points. This study 153 adopted the K-Bessel SVM which uses empirical transformations in simple remodeling. A study 154 by Krivoruchko, (2011) noted that the method mentioned above is the most applicable, explicit 155 and reliable technique but with a limitation of prolonged processing time.

\section{$156 \quad 2.1 \quad$ Health risk assessment}

157 Health risk assessment is a verified method that has been adopted extensively for the evaluation 158 of potential hazards on human health after being exposed to certain chemicals over a period (US 
159 EPA, 1989). In this study, the potential health risk of fluoride concentration on the population was 160 evaluated. Due to the behavioral and physiological attributes of different age groups, the 161 population was divided into seven age categories (6-12 months, 6-11 years, 11-16 years, 16-18 162 years, 18-21 years, $\geq 21$ years and $>$ 65years) assessed from the US EPA exposure factor handbook 163 (US EPA, 2011). Several pathways have been identified through which humans can be exposed to 164 chemical risk. They include inhalation, dermal and ingestion pathways. However, this study 165 considered dermal and ingestion pathways only because of the unavailability of the transfer 166 efficiency of fluoride from water to air and its inhalation reference dose. Furthermore, inhalation 167 was not considered as a major exposure route for fluoride (National Academy of Science, 2006) 168 The chronic daily dose of fluoride via ingestion and dermal pathways were estimated using Eqn. 169 (1) and Eqn. (2) based on (US EPA, 2011) recommendation.

$$
C D D_{I N}=\frac{C_{f w} \times I R_{w} \times E F_{r} \times E D}{B W \times A T_{r}}
$$

172 Where $C D D_{I N}$ and $C D D_{D E}$ are the estimated chronic daily dose of fluoride via ingestion and 173 dermal exposure route respectively $(\mu \mathrm{g} / \mathrm{kg} \bullet$ day $) ; C_{f w}$ is the concentration of fluoride in drinking 174 water $(\mu \mathrm{g} / L) ; I R_{w}$ is the ingestion rate ( $L /$ day); $S A$ is the exposed skin area $\left(\mathrm{cm}^{2}\right) ; K_{p}$ is the 175 dermal permeability coefficient for water (unitless); $E F_{r}$ is the resident exposure frequency 176 (days / year); ED is the exposure duration (year); ET is the water exposure time (hours / day); $177 B W$ is body weight $(\mathrm{kg}) ; A T_{r}$ is the averaging resident time(days / year) and $C F$ is the unit 178 conversion factor $\left(L / \mathrm{cm}^{3}\right)$. 
179 The hazard quotient (HQ) of fluoride exposure via ingestion and dermal pathways was calculated 180 using Eqn. (3) and Eqn. (4)

$$
H Q_{I N}=\frac{C D D_{I N}}{R f D}
$$

$$
H Q_{D E}=\frac{C D D_{D E}}{R f D}
$$

183 Where $H Q_{I N}$ and $H Q_{D E}$ are the ingestion hazard quotient and dermal hazard quotient respectively;

$184 R f D$ is the reference dose of fluoride (equals $0.06 \mathrm{mg} / \mathrm{kg}$-day according to the Integrated Risk 185 Information System (IRIS) database of the US EPA) in a particular route. The reference values of 186 each parameter used for calculating the $C D D_{I N}, C D D_{D E}, H Q_{I N}$ and $H Q_{D E}$ are compiled in Table

187 S1 (in the supplementary material).

\section{$188 \quad 2.2 \quad$ Data analysis}

189 After the analyses of the water samples, the results were subject to descriptive statistical analyses.

190 For each water quality parameter, the mean, minimum, maximum, and quartiles were calculated 191 using GraphPad Prism 6 for Windows (GraphPad Software Inc.). The geospatial map of fluoride 192 contamination and water quality parameters was achieved using ArcMap 10.3.1. The principal 193 component analysis (influence plot, scree plot, score plot and loading plot) and correlation matrix

194 were executed using Unscrambler X (CAMO software AS, version 10.4). The representation of 195 the different water types on a Piper diagram was achieved using Rockworks17 64bit. The EBK 196 model and semivariogram plots were calculated using geostatistical analyst tool in ArcMap 10.3.1. 


\section{Results and discussion}

200

201

202

203

204

205

206

207

208

209

210

211

212

213

214

215

216

217

218 219 levels (Wayland et al., 2003).

220

$\mathrm{HCO}_{3}{ }^{-}$and $\mathrm{CO}_{3}{ }^{2-}$ concentrations were observed in the range from 278.30 to $666.27 \mathrm{mg} / \mathrm{L}$ and $0-$

221

Within the study region, the TDS and EC values ranged from 498.33 to $2126.00 \mathrm{mg} / \mathrm{L}$ and 665.33 to $3314.67 \mu \mathrm{S} / \mathrm{cm}$ respectively (Table S2). According to the results, $4.76 \%$ of the TDS samples were in a range considered desirable for drinking, $42.86 \%$ were in the permissible for drinking category and, 52.85\% were useful for irrigation purposes as defined by WHO standards (WHO, 2011). Concerning EC, 23.80\% were within the permissible limits for drinking, and the remaining 76.2\% exceeded WHO stipulated standards. The cause of the increased TDS and EC concentrations could be due to heavy application of agro-chemicals, rainwater percolation, ion exchange and sediment dissolution (Chabukdhara et al., 2017). Relating the results of other water quality parameters with WHO guidance for drinking water (WHO, 2011), $\mathrm{Cl}^{-}$values varied from $32.60 \mathrm{mg} / \mathrm{L}$ to $546.20 \mathrm{mg} / \mathrm{L}$ in all samples with $19 \%$ of samples exceeding the WHO threshold. The presence of chloride originates from dissolved chloride salts found in minerals as well as animal and human waste. Moreover, the heightened chloride concentration may be as a result of industrial and commercial activities within these zones.

$\mathrm{Na}^{+}$concentration varied from $55.97 \mathrm{mg} / \mathrm{L}$ to $514.73 \mathrm{mg} / \mathrm{L}$. Out of the twenty-one locations sampled, only eight locations revealed $\mathrm{Na}^{+}$concentration exceeding the WHO threshold of 200 mg/L. It was evident that all locations had a high degree of variability in $\mathrm{Na}^{+}$and $\mathrm{Cl}^{-}$concentrations with high standard deviation values of \pm 112.88 and \pm 140.88 respectively. It should be noted that $\mathrm{Na}^{+}$can be caused by cation exchange processes that occur in the aquifer. Furthermore, wastewater pollution from anthropogenic sources and intrusion from septic tanks may also increase sodium

$25.67 \mathrm{mg} / \mathrm{L}$ respectively. The concentration of $\mathrm{HCO}_{3}$-in the region exceeded WHO recommended 
222 levels of $500 \mathrm{mg} / \mathrm{L}$ in $14.30 \%$ of the samples. Meanwhile, no permissible limit has been provided

223 by the WHO standards for $\mathrm{CO}_{3}{ }^{2-}$ in drinking water. Elevated levels of bicarbonate were likely to

224 be from natural dissolution from rocks, as well as runoff, irrigation, and infiltration processes

225 having contact with the groundwater systems during recharge (Rasool et al., 2016; Singh et al., 226 2013).

227 From the results displayed in Table S2, it was observed that $\mathrm{SO}_{4}{ }^{2-}$ values varied from $35.73 \mathrm{mg} / \mathrm{L}$ 228 to $978.60 \mathrm{mg} / \mathrm{L}$. When the $\mathrm{SO}_{4}{ }^{2-}$ values were compared with WHO guidelines for drinking water, $22942.9 \%$ of the samples exceeded these limits. It is important to note here that elevated $\mathrm{SO}_{4}{ }^{2-}$ 230 concentrations in drinking water may result in respiratory illnesses (Subba Rao, 1993). $\mathrm{NO}_{3}^{-}$ 231 concentrations ranged from $0.00 \mathrm{mg} / \mathrm{L}$ to $25.67 \mathrm{mg} / \mathrm{L}$. These $\mathrm{NO}_{3}{ }^{-}$concentrations were low and 232 within permissible limits, although its presence in water is attributed to anthropogenic activities 233 resulting from fertilizer use (Tirkey et al., 2017).

$234 \mathrm{Ca}^{2+}$ and $\mathrm{Mg}^{2+}$ are important indicators of water hardness. Within the study area, $\mathrm{Ca}^{2+}$ values were 235 within the permissible limits (200 mg/L) set by WHO except for sample point R17 (227.67 mg/L) 236 that exceeded the limit. Some 33.33\% of the water samples exceeded the WHO most desirable 237 limits $(75 \mathrm{mg} / \mathrm{L})$ for $\mathrm{Ca}^{2+}$ while $52.38 \%$ of the analyzed water samples were above the WHO most 238 desirable limit (50 mg/L) for $\mathrm{Mg}^{2+}$ concentration in drinking water. The reason for the variability 239 of $\mathrm{Mg}^{2+}$ concentration may be associated with ion exchange linked with dissolved rock and soil 240 minerals in the water. $\mathrm{K}^{+}$and $\mathrm{Fe}^{2+}$ values ranged from 2.07 to $9.30 \mathrm{mg} / \mathrm{L}$ and 0.02 to $2.96 \mathrm{mg} / \mathrm{L}$ 241 respectively. All samples showed $\mathrm{K}^{+}$concentration lower than the WHO threshold but the $\mathrm{Fe}^{2+}$ 242 concentration surpassed the WHO allowable limits in $38.10 \%$ of the samples. Although iron is not 243 regarded as hazardous to human health, its presence could be seen as a nuisance or aesthetic 244 pollutant. $\mathrm{Fe}^{2+}$ often coexists with $\mathrm{Mn}$, which was found to be lower than the allowable limits 
245 recommended by WHO guidelines for drinking water (WHO, 2011) in all samples. The co-

246 existence of $\mathrm{Mn}$ and $\mathrm{Fe}^{2+}$ is proposed to occur from the natural dissolution from gneiss and biotite

247 rock formation. Furthermore, a study by Magesh et al. (2017) showed that a deep groundwater

248 aquifer could be laden with $\mathrm{Fe}^{2+}$ if ionic activities in aquifers were high.

249 The concentration of $\mathrm{F}^{-}$ranged from 0.48 to $1.84 \mathrm{mg} / \mathrm{L}$ with a mean value of $1.23 \mathrm{mg} / \mathrm{L}$. It was

250 observed that $33 \%$ of the samples surpassed the WHO allowable limits for fluoride ion

251 concentration in drinking water $(1.5 \mathrm{mg} / \mathrm{L})$. This result suggests that inhabitants may be faced with

252 the risk of fluorosis, from consumption of this water. On the other hand, dental caries may be a

253 risk when the fluoride content in drinking water falls below $0.5 \mathrm{mg} / \mathrm{L}$. In line with this, it was also

254 discovered that $14 \%$ of the samples had fluoride concentrations less than $0.5 \mathrm{mg} / \mathrm{L}$, while $52.4 \%$

255 had fluoride concentration ranging from 0.5 to $1.5 \mathrm{mg} / \mathrm{L}$ which is the adequate dose for the

256 development of healthy bones and teeth.

$257 \quad$ Water Quality Assessment

258 The hydrogeochemical facies of the region was characterized using Piper diagrams. The Piper plot 259 consists of two triangles and a diamond-shaped diagram (Fig. 2a). The two triangles represent the 260 plot of anion and cations, while the diamond-shaped plot shows the combination of the anion and 261 cation fields. The concept of hydrogeochemical facies is derived from regions that contain 262 identifiable characteristics of different anion and cation concentrations within the diamond-shape 263 diagram.

264 From the Piper plot, it was observed that $\mathrm{Na}^{+}$and $\mathrm{K}^{+}$were the dominant cations. Nevertheless, $265 \mathrm{Ca}^{2+}$ and $\mathrm{Mg}^{2+}$ also contributed to the overall classification. In the anion region, $\mathrm{HCO}_{3}{ }^{-}$and $\mathrm{SO}_{4}{ }^{2-}$ 266 dominated the facies. With $\mathrm{Na}^{+}$dominating over other cations, it suggests the occurrence of ion 
267 exchange activities as a result of rock weathering. However, the dominance of $\mathrm{HCO}_{3}{ }^{-}$and $\mathrm{SO}_{4}{ }^{2-}$ 268 also reveals ion contributions from silica weathering (Achary et al., 2016; Giridharan et al., 2009).

269 In corroboration, Aghazadeh et al., (2016) and Barzegar et al., (2017) remarked that if the ratio of

$270 \mathrm{Ca}^{+} / \mathrm{Mg}^{2+}$ ranges from 0.6 to any value greater than 2, it signifies the dissolution of dolomite and

271 silicate rock materials in groundwater. After estimating the ratio of $\mathrm{Ca}^{+} / \mathrm{Mg}^{2+}$, the majority of the

272 water samples (71.43\%) produced ratios ranging from 0.65 to 5.24, indicating the interference of

273 silicate and dolomitic constituents in the groundwater system. However, the general classification

274 of all samples suggests $9 \% \mathrm{Ca}-\mathrm{Mg}-\mathrm{Cl}-\mathrm{SO}_{4}, 24 \% \mathrm{Ca}-\mathrm{Mg}-\mathrm{HCO}_{3}, 29 \% \mathrm{Na}-\mathrm{K}-\mathrm{Cl}-\mathrm{SO}$, and $38 \%$

$275 \mathrm{Na}-\mathrm{K}-\mathrm{HCO}_{3}$ water types.

\section{$276 \quad 3.2 \quad$ Multivariate statistical investigation}

277 Pearson's correlation analysis calculations have been deployed by different researchers in water

278 quality evaluation to obtain the controlling ion in the hydrochemical process (P. C. Emenike et al., 279 2017; Giridharan et al., 2009; Li et al., 2013; Rasool et al., 2016). The data obtained from the CA 280 served as a proportional measure to represent the association of one variable with the other. This 281 study examined the interrelationships between the water quality parameters. In cases where the 282 correlation coefficient $(r)$ was less than 0.3, the relationship is regarded as a weak correlation. If $r$ 283 value ranges from 0.3 to 0.7 , the relationship was considered moderate, and when the value of $r$ 284 was greater than 0.7 it is considered strong (Salifu et al., 2012; Xiao et al., 2015)

285 From the physico-chemical correlationships (Table S3 in the supplementary material), fluoride 286 was seen to have a strong positive relationship with TDS $(r=0.79), \mathrm{SO}_{4}{ }^{2-}(r=0.35), \mathrm{EC}(r=$ 287 0.40), and $\mathrm{Mg}^{2+}(r=0.34)$. Similarly, fluoride showed a weak but positive relationship with $\mathrm{Ca}^{2+}$ $288(r=0.23)$. Other relationships that can be drawn from the analysis show that there was a moderate 289 positive correlation between $\mathrm{pH}$ and TDS ( $r=0.41)$, EC $(r=0.38)$, Alka $(r=0.46), \mathrm{Fe}^{2+}(r=$ 
0.50) and $\mathrm{Cl}^{-}(r=0.34)$. Similarly, a moderate negative relationship existed between $\mathrm{pH}-\mathrm{K}^{+}(r$

$291=-0.45)$ and $\mathrm{pH}-\mathrm{SiO}_{2}(r=-0.50)$.

292 In addition, the statistical analysis showed a strong positive inter-relationship between TDS - EC $293(r=0.91), \mathrm{TDS}-\mathrm{Mg}^{2+}(r=0.78), \mathrm{TDS}-\mathrm{SO}_{4}{ }^{2-}(r=0.78)$. Moderate positive inter-relationships 294 exist between TDS $-\mathrm{Ca}^{2+}(r=0.44)$, TDS $-\mathrm{Na}^{+}(r=0.49), \mathrm{TDS}-\mathrm{HCO}_{3}^{-}(r=0.66)$ and TDS $295 \mathrm{Cl}^{-}(r=0.59)$. However, a moderate negative relationship existed between TDS $-\mathrm{SiO}_{2}(r=-0.56)$

296 The statistical study identified moderate positive correlations for EC $-\mathrm{K}^{+}(r=0.34), \mathrm{EC}-\mathrm{Ca}^{+}(r$ $297=0.64), \mathrm{EC}-\mathrm{Mg}^{2+}(r=0.57), \mathrm{EC}-\mathrm{Na}^{+}(r=0.34), \mathrm{EC}-\mathrm{HCO}_{3}^{-}(r=0.65), \mathrm{EC}^{-} \mathrm{Cl}^{-}(r=0.54)$ 298 and a strong positive correlation for $\mathrm{EC}-\mathrm{SO}_{4}{ }^{2-}(r=0.79)$. Other moderate positive relationships 299 were seen in the results between $\mathrm{Ca}^{2+}-\mathrm{SO}_{4}{ }^{2-}(r=0.66), \mathrm{Mg}^{2+}-\mathrm{SO}_{4}{ }^{2-}(r=0.66), \mathrm{SO}_{4}{ }^{2-}-\mathrm{HCO}_{3}{ }^{-}$ $300(r=0.65)$ while a strong positive relationship existed between $\mathrm{Na}^{+}-\mathrm{Cl}^{-}(r=0.84)$ and $\mathrm{SO}_{4}{ }^{2-}-$ $301 \mathrm{Cl}^{-}(r=0.76)$.

302 In comparison, the average concentration of $\mathrm{F}^{-}$obtained from this study were higher than the mean 303 values obtained from the Birbhum district (Das and Nag, 2017), the Northern region of Ghana 304 (Salifu et al., 2012), the Varahi river basin (Ravikumar and Somashekar, 2017) and less than that 305 seen in the South of India (Viswanathan et al., 2009), Northern Tanzania (Shen and Schäfer, 2015), 306 and Umarkot sub-district, Pakistan (Rafique et al., 2015). It is important to note that the 307 concentration of fluoride in water tends to increase when the TDS value is high (Rafique et al., 308 2009). Also looking at fluoride concentration with respect to $\mathrm{pH}$, Guo et al., (2012) noted that at $309 \mathrm{pH} 5.0-6.5$, the solubility of fluoride is at its lowest. Saxena and Ahmed (2001) observed that the 310 dissolution of fluoride occurs between $\mathrm{pH} 6$ to $\mathrm{pH}$ 9. In this study, the $\mathrm{pH}$ of the water was 6.76, 311 a condition where the solubility of fluoride was expected to be high. The presence of fluoride in 312 water may be as a result of dissolution from quartzite and paleosols near the underlying 
313 groundwater table (Amanambu and Egbinola, 2015; Chuah et al., 2016; Xiao et al., 2015) and it

314 could be the reason for the moderate positive relationship existing between $\mathrm{F}^{-}$and $\mathrm{pH}(\mathrm{r}=0.53)$.

315 Also, in the correlation matrix (Table S3 in the supplementary material), fluoride ions had a strong

316 positive relationship with TDS $(r=0.79)$ and a moderate relationship with EC $(r=0.40), \mathrm{Mg}^{2+}(r$

$317=0.34), \mathrm{SO}_{4}{ }^{2-}(r=0.35)$, and Alkalinity $(r=0.40)$. The moderate positive correlation between $\mathrm{F}^{-}$

318 and alkalinity confirms the penetration of fluoride enriched minerals from an alkaline environment

319 into the groundwater systems.

\section{$321 \quad 3.3 \quad$ Principal component analysis (PCA) of water parameters}

322 PCA is a widely used technique that explains the variation in a large dataset where the variables

323 are interconnected. It extracts information from the data by reducing dimensionality through 324 variable reduction as well as qualitative structure-activity relationship. The interpretation of

325 principal components (PC) can be linked to the hydrochemical characteristics of water samples.

326 The loadings on each PC explains the water-rock interactions in the geochemical process (Fig. 2b).

327 The most important parameters controlling the hydrochemical processes are mainly found in PC1,

328 having the highest Eigenvalue. In this study, PCA was performed, and from the scree plot and 329 explained variance (Fig. 2c), the PCA produced two components PC1 and PC2. PC1 contributed $33090.09 \%$ of the total variance. Within the total variance explained by PC1, strong positive loadings 331 were recorded in EC $(r=0.9889)$, TDS $(r=0.9599), \mathrm{SO}_{4}{ }^{2-}(r=0.8335), \mathrm{HCO}_{3}^{-}(r=0.6780)$, $332 \mathrm{Mg}^{2+}(r=0.6597), \mathrm{Ca}^{2+}(\mathrm{r}=0.5999), \mathrm{Cl}^{-}(r=0.6003)$ and high negative loadings in $\mathrm{SiO}_{2}(r=-$ 333 0.5243). Considering the loadings mentioned above, PC1 can be regarded as a salinity index. PC2 334 explains $4.61 \%$ of the total variance with high negative loadings from $\mathrm{Na}^{+}(r=-0.7052), \mathrm{Cl}^{-}(r=$ $335-0.6128)$ and $\mathrm{Mg}^{2+}(r=-0.4519)$. 
336 The positive loading of $\mathrm{pH}$ on PC1 suggests an interaction between silicate and carbonate 337 materials. It also suggests dissolution processes involving gneiss and granite rock formations, 338 which may be the reason for the dominance of $\mathrm{Ca}^{2+}, \mathrm{HCO}_{3}{ }^{-}$and $\mathrm{Mg}^{2+}$. These results support earlier 339 works of Oke and Tijani (2012) and Ufoegbune et al. (2009), where it was observed that the 340 geological formation of Abeokuta is mainly sedimentary and basement rocks of Paleozoic age 341 enriched with $\mathrm{MgO}, \mathrm{SiO}_{2}, \mathrm{~K}_{2} \mathrm{O}$, and $\mathrm{CaO}$. Concurrently, an increase in $\mathrm{pH}$ was seen when protons 342 were consumed during the dissolution process. This may also be the reason why the $\mathrm{pH}$ had a 343 positive loading on PC1. The varying $\mathrm{pH}$ values observed in these results is an indication that the 344 groundwater system must have been recharged with water that passed through rock formations 345 with a significant amount of salt.

346 Concerning the dominating parameters in PC1, the high positive loadings may be as a result of 347 dissolved porphyritic biotite granite and porphyroblastic gneiss. This result supports the findings 348 of Oke and Tijani, (2012) and confirms the presence of these rock formations contributing to the 349 increase in TDS, EC, $\mathrm{HCO}_{3}{ }^{-}, \mathrm{Mg}^{2+}, \mathrm{Ca}^{2+}$, and $\mathrm{Cl}^{-}$loadings recorded in PC1. The presence of these 350 components represents a combined process comprising chemical weathering and mineralogical 351 dissolution of rock constituents.

352 The score plot (Fig. 2d) accounts for the information and similarities within the samples analyzed 353 and helps to understand the spatial distribution of the samples. From Fig. 2d, samples R14, R19, 354 R12, R18, R13, and R21, were observed to have characteristics of similar water quality. 355 Interestingly, within the samples, the total variance explained by PC1 (90.09\%) received a high 356 loading from R12 ( $r=-737.455), \mathrm{R} 13(r=-827.740), \mathrm{R} 14(r=-1146.254), \mathrm{R} 18(r=-705.517)$, 357 R21 ( $r=-805.961)$, R19 $(r=-962.665)$ and R4 $(r=-1053.184)$. Also from the results, the 358 contribution from PC2 to the score plot emanates from R11 ( $r=-697.740)$. Similar contributions 
can be seen from R6 and R7 with scores $r=-258.166$ and $r=-310.154$ respectively. The influence plot showing how the different samples contribute to the components is presented in Fig. 2 (e).

\section{"Fig. 2(a-e) is about here."}

\subsection{Geostatistical modeling}

After analyzing the water quality parameters with the EBK model, the spatial distribution maps of all examined parameters are presented in Fig. 3(a-p). Four important factors revealed by the prediction statistics of the EBK model explained the authenticity of the model. They include, root mean squared predicted (RMSP), average standard error (ASE), mean standardized (MS), and root mean square standardized (RMSS) statistics. The results obtained established the potency of the different distribution of the EBK prediction model, one of which is associated with the closely related values of the ASE and RMSP values. From the results presented in Table 1, it could be seen that the ASE and RMSP are near, signifying the validity of the prediction. It is also important to note that RMSS should be close to 1 to explain the extent of estimation of the EBK model further. If the RMSS is $>1$, the prediction is said to be overestimated and if $<1$, the prediction is underestimated. Therefore, the results revealed the RMSS value of pH as 0.968; TDS, 0.967; EC, 0.966; F$-0.979 ; \mathrm{Fe}^{2+}, 0.999 ; \mathrm{Mn}, 0.998 ; \mathrm{Ca}^{2+}, 0.966, \mathrm{~K}^{+}, 0.993 ; \mathrm{Mg}^{2+}, 0.970 ; \mathrm{Na}^{+}, 0.975 ; \mathrm{SO}_{4}^{2-}$, 0.910, $\mathrm{SiO}_{2}, 0.981, \mathrm{HCO}_{3}{ }^{-}, 0.986 ; \mathrm{Cl}^{-}, 0.972 ; \mathrm{NO}_{3}{ }^{-}, 0.959$ and $\mathrm{CO}_{3}{ }^{2-}, 0.986$-authenticating the variability prediction since all values are close to 1 . Furthermore, the MS value should be close to 0 for the prediction to be valid. This is confirmed, as the MS values in this study ranged from 0.072 to 0.092 . 
382 In the semivariograms of the examined water parameters (Fig 4a-4p), the blue crosses represent 383 the semivariance obtained from empirical transformation, the bold red lines represent the 384 intermediate distribution, the faint blue plots describe the different semivariograms distribution, 385 the faded red plots (dotted) displays the $25^{\text {th }}$ and $75^{\text {th }}$ percentile respectively, and the densely386 packed blue lines indicate the series of semivariogram passing through the zone. To examine the 387 stability of the model, the majority of the blue crosses should remain within the confines of the 388 faint blue spectrum (Magesh et al., 2017; Tenebe et al., 2018, 2017). This was the case observed 389 for all of the water parameters studied.

“Fig. 4 is about here."

\section{$391 \quad 3.5 \quad$ Fluoride risk assessment}

\section{Ingestion risk}

393 The hazard quotient (HQ) associated with fluoride concentration on different age classification (6-

39412 months, 6-11 years, 11-16 years, 16-18 years, 18-21 years, $\geq 21$ years and $>65$ years) was 395 evaluated, integrating the indicators obtained from the US EPA Exposure Factor Handbook (US 396 EPA, 2011) as well as the fluoride concentration in the groundwater from the sampled locations.

397 The non-carcinogenic risks were computed, and the age classification with high values of $H Q_{I N}$ 398 are presented in Table 2 and Table S4 (in the supplementary material). The mean $C D D_{I N}$ values 399 ranged from 53.846-201.832 $\mu \mathrm{g} /\left(\mathrm{kg}\right.$ day) for age 6-12 months. The mean $C D D_{\text {IN }}$ values for age 6 $400-11$ years varied from 22.075 to $82.744 \mu \mathrm{g} /(\mathrm{kg}$ day $)$. The mean $C D D_{I N}$ values for age $11-16$ years 401 varied from 16.454 to $61.674 \mu \mathrm{g} /(\mathrm{kg}$ day). Similarly, the mean CDDs for age classifications 1640218 years, $18-21$ years, $\geq 21$ years and $>65$ years varied from 12.902 to $48.362 \mu \mathrm{g} /(\mathrm{kg}$ day $), 16.962$ 
to $63.577 \mu \mathrm{g} /(\mathrm{kg}$ day), 18.282 to $68.525 \mu \mathrm{g} /(\mathrm{kg}$ day) and 16.721 to $62.672 \mu \mathrm{g} /(\mathrm{kg}$ day) respectively,

404 in relation to water ingestion (Table S4 in the supplementary material). After computing the $H Q_{I N}$,

405 further observation revealed that $90.5 \%$ of the sampled locations were above the permissible level

406 because for age classification 6-12 months, because the $H Q_{I N}$ values were greater than 1 . The

407 implication is that the children in the 6-12 months age range are more likely to suffer from health

408 complications associated with consumption of water laden with a high concentration of fluoride

409 (Ding et al., 2011). Also, children within the age range of 6 - 11 years were also expected to be

410 affected as $42.9 \%$ of the sampled region exceeded the $H Q_{I N}$ limits.

411 Furthermore, $4.8 \%$ of the modelled exposures surpassed the acceptable $H Q_{I N}$ limit for age classes

412 11-16 years and > 65 years, 9.5\% of the sampled region exceeded the permissible $H Q_{I N}$ level for

413 age 18-21years, $19.05 \%$ of the study location was beyond the allowable $H Q_{I N}$ limits for age $\geq 21$

414 years. No risk was modelled for age class 16 - 18 years in the region. Despite the fact that age

415 classifications $11-16$ years, $18-21$ years, $\geq 21$ years and $>65$ years had overall low percentage

416 risks, it was observed that at specific locations (R16 and R17), much higher risks were seen across

417 all age classifications noted above. This identifies explicitly the need for more extensive water

418 treatment at locations R16 and R17 since the region is prone to high fluoride concentrations in the

419 tap water.

420

421 Dermal risk

422 Table S5 (in the supplementary material) and Table 3 shows the dermal $C D D_{D E}$ and $H Q_{D E}$ values

423 respectively. The dermal mean $C D D_{D E}$ varied from $0.125 \mu \mathrm{g} /(\mathrm{kg}$ day) to $0.470 \mu \mathrm{g} /(\mathrm{kg}$ day $)$ and

$4240.111 \mu \mathrm{g} /(\mathrm{kg}$ day $)$ to $0.418 \mu \mathrm{g} /(\mathrm{kg}$ day $)$ for age classification 6 -12months and 6-11years 
425 respectively. Correspondingly, the $C D D_{D E}$ for age class 11-16years and 16-18years varied from

$4260.073 \mu \mathrm{g} /(\mathrm{kg}$ day) to $0.275 \mu \mathrm{g} /(\mathrm{kg}$ day) and $0.068 \mu \mathrm{g} /(\mathrm{kg}$ day $)$ to $0.253 \mu \mathrm{g} /(\mathrm{kg}$ day $)$. After

427 computing the chronic daily dose as a result of dermal exposure $\left(C D D_{D E}\right)$ for age class $18-21$ years,

$428 \geq 21$ years and $>65 y$ ears, the values ranged from $0.096 \mu \mathrm{g} /(\mathrm{kg}$ day) to $0.362 \mu \mathrm{g} /(\mathrm{kg}$ day), 0.083

$429 \mu \mathrm{g} /(\mathrm{kg}$ day) to $0.310 \mu \mathrm{g} /(\mathrm{kg}$ day) and $0.081 \mu \mathrm{g} /(\mathrm{kg}$ day) to $0.303 \mu \mathrm{g} /(\mathrm{kg}$ day) respectively. The

$430 H Q_{D E}$ obtained in this study suggests low risk via dermal exposure for all age classification $\left(H Q_{D E}\right.$

$431-1)$. However, the HQDE values presented in the results establish the need for attention, especially

432 now that the aftermath of climate change poses significant change to groundwater resources.

433 Significant health impediments, in addition to dental and skeletal fluorosis, such as

434 neurotoxicological diseases (Choi et al., 2012), skeletal cancer (Bassin et al., 2006), hypertension

435 (Sun et al., 2013), carotid artery atherosclerosis (Liu et al., 2014) and cardiac dysfunction (Varol

436 et al., 2010) or possibly death may occur due to long-term exposure of fluoride. In other words, if

437 the current trend of fluoride contamination occurs continuously in the study area, the devastating

438 effect on lives will be enormous since survival possibilities rely on the availability of clean (non-

439 contaminated) drinking water (Emenike et al., 2017).

440 4. Conclusion

441 The different ionic concentration of groundwater, fluoride concentration and its associated health 442 risk were investigated in Abeokuta, Nigeria. Considering the water quality of the sixty-three taps 443 analyzed, only about 5\% were found to be fit for consumption (based on the percentage violation 444 of TDS from WHO standards). According to the WHO guidelines for drinking water quality 445 (WHO, 2011), parameters such as TDS, EC, $\mathrm{F}^{-}$and $\mathrm{SO}_{4}{ }^{2-}$ exceeded allowable limits. The findings 446 in this study revealed that chemical weathering and dissolved rock compounds were responsible 447 for the presence of $\mathrm{F}^{-}, \mathrm{HCO}_{3}^{-}, \mathrm{Mg}^{2+}$, high TDS and $\mathrm{EC}$ in the groundwater. The CA and PCA 
448 techniques validate the interrelationship of elements and its potential source as it reveals a 449 statistical relationship between $\mathrm{F}^{-}$and TDS, EC, Alkalinity, $\mathrm{Mg}^{2+}$, and $\mathrm{SO}_{4}{ }^{2-}$. The classification of 450 the water types could be ranked as $\mathrm{Na}-\mathrm{K}-\mathrm{HCO}_{3}-\mathrm{Na}-\mathrm{K}-\mathrm{Cl}-\mathrm{SO}_{4}-\mathrm{Ca}-\mathrm{Mg}-\mathrm{HCO}-\mathrm{Ca}-\mathrm{Mg}-\mathrm{Cl}-$ $451 \mathrm{SO}_{4}$ type. The information obtained from the EBK model validates the prediction of the spatial 452 distribution as the standardized RMS values were close to 1 Also, the values of ASE and RMSP 453 were almost equal which validates the authenticity of the spatial model. Further observation 454 revealed that $90.5 \%$ of the modelled exposure was above the standard level for age classification 455 6-12 months. 4.8\% of the modelled exposures exceeded the acceptable $H Q_{I N}$ limit for age classes 456 11-16 years and $>65$ years, 9.5\% of the sampled region exceeded the permissible $H Q_{I N}$ level for 457 age $18-21$ years and $19.05 \%$ of the study location was beyond the allowable HQIN limits for age $\geq$ 45821 years.

459 Acknowledgement

460 The authors wish to thank the management of Covenant University for the enabling atmosphere 461 for the research. We want to also appreciate the advice given by Dr. Jitka MacAdam (Cranfield 462 Water Science Institute. School of Water, Energy and Environment, Cranfield University, United 463 Kingdom). Also, we wish to thank the anonymous reviewers for their technical contributions 464 required to bring this paper to this state. 


\section{References}

466

467

468

469

470

471

472

473

474

475

476

477

478

479

480

481

482

483

484

485

486

487

488

489

490

491

492

493

494

495

496

497

498

499

500

501

502

Achary, M.S., Panigrahi, S., Satpathy, K.K., Prabhu, R.K., Panigrahy, R.C., 2016. Health risk assessment and seasonal distribution of dissolved trace metals in surface waters of Kalpakkam, southwest coast of Bay of Bengal. Reg. Stud. Mar. Sci. 6, 96-108. https://doi.org/10.1016/j.rsma.2016.03.017

Adekunle, A.A., Adedayo O. Badejo, Abiola O. Oyerinde, 2013. Pollution Studies on Ground Water Contamination: Water Quality of Abeokuta, Ogun State , South West Nigeria. J. Environ. Earth Sci. 3, 161-166.

Aghazadeh, N., Chitsazan, M., Golestan, Y., 2016. Hydrochemistry and quality assessment of groundwater in the Ardabil area , Iran. Appl. Water Sci. 7, 3599-3616. https://doi.org/10.1007/s13201-016-0498-9

Amanambu, A.C., Egbinola, C.N., 2015. Geogenic contamination of groundwater in shallow aquifers in Ibadan, south-west Nigeria. Manag. Environ. Qual. An Int. J. 26, 327-341. https://doi.org/10.1108/MEQ-12-2013-0135

Amini, M., Abbaspour, K.C., Berg, M., Winkel, L., Hug, S.J., Hoehn, E., Yang, H., Johnson, C.A., 2008. Statistical modeling of global geogenic arsenic contamination in groundwater. Env. Sci Technol 42, 3669-3675.

Barzegar, R., Asghari Moghaddam, A., Tziritis, E., 2017. Hydrogeochemical features of groundwater resources in Tabriz plain, northwest of Iran. Appl. Water Sci. https://doi.org/10.1007/s13201-017-0550-4

Bassin, E.B., Wypij, D., Davis, R.B., Mittleman, M.A., 2006. Age-specific fluoride exposure in drinking water and osteosarcoma (United States). Cancer Causes Control 17, 421-428. https://doi.org/10.1007/s10552-005-0500-6

Battaleb-Looie, S., Moore, F., Malde, M.K., Jacks, G., 2013. Fluoride in groundwater, dates and wheat: Estimated exposure dose in the population of Bushehr, Iran. J. Food Compos. Anal. 29, 94-99. https://doi.org/10.1016/j.jfca.2012.08.001

Bhatnagar, A., Kumar, E., Sillanpää, M., 2011. Fluoride removal from water by adsorption-A review. Chem. Eng. J. 171, 811-840. https://doi.org/10.1016/j.cej.2011.05.028

Chabukdhara, M., Gupta, S.K., Kotecha, Y., Nema, A.K., 2017. Groundwater quality in Ghaziabad district, Uttar Pradesh, India: Multivariate and health risk assessment. Chemosphere 179, 167-178. https://doi.org/10.1016/j.chemosphere.2017.03.086

Choi, A.L., Sun, G., Zhang, Y., Grandjean, P., 2012. Developmental Fluoride Neurotoxicity: A Systematic Review and Meta-Analysis. Environ. Health Perspect. 1362, 1362-1368.

Chuah, C.J., Lye, H.R., Ziegler, A.D., Wood, S.H., Kongpun, C., Rajchagool, S., 2016. Fluoride: A naturally-occurring health hazard in drinking-water resources of Northern Thailand. Sci. Total Environ. 545-546, 266-279. https://doi.org/10.1016/j.scitotenv.2015.12.069

Craig, L., Lutz, A., Berry, K.A., Yang, W., 2015. Recommendations for fluoride limits in drinking water based on estimated daily fluoride intake in the Upper East Region, Ghana. Sci. Total 
Environ. 532, 127-137. https://doi.org/10.1016/j.scitotenv.2015.05.126

Das, S., Nag, S.K., 2017. Application of multivariate statistical analysis concepts for assessment of hydrogeochemistry of groundwater-a study in Suri I and II blocks of Birbhum District, West Bengal, India. Appl. Water Sci. 7, 873-888. https://doi.org/10.1007/s13201-015-02996

Dehbandi, R., Moore, F., Keshavarzi, B., 2018. Geochemical sources, hydrogeochemical behavior, and health risk assessment of fluoride in an endemic fluorosis area, central Iran. Chemosphere 193, 763-776. https://doi.org/10.1016/j.chemosphere.2017.11.021

Ding, Y., YanhuiGao, Sun, H., Han, H., Wang, W., Ji, X., Liu, X., Sun, D., 2011. The relationships between low levels of urine fluoride on children's intelligence, dental fluorosis in endemic fluorosis areas in Hulunbuir, Inner Mongolia, China. J. Hazard. Mater. 186, 1942-1946. https://doi.org/10.1016/j.jhazmat.2010.12.097

Emenike, C.P., Tenebe, I.T., Omole, D.O., Ngene, B.U., Oniemayin, B.I., Maxwell, O., Onoka, B.I., 2017. Accessing safe drinking water in sub-Saharan Africa: Issues and challenges in South-West Nigeria. Sustain. Cities Soc. 30, 263-272. https://doi.org/10.1016/j.scs.2017.01.005

Emenike, P.C., Omole, D.O., Ngene, B.U., Tenebe, I.T., 2016. Potentiality of agricultural adsorbent for the sequestering of metal ions from wastewater. Glob. J. Environ. Sci. Manag. 2, 411-442. https://doi.org/10.22034/gjesm.2016.02.04.010

Emenike, P.C., Tenebe, T.I., Omeje, M., Osinubi, D.S., 2017. Health risk assessment of heavy metal variability in sachet water sold in Ado-Odo Ota, South-Western Nigeria. Environ. Monit. Assess. 189, 1-16. https://doi.org/10.1007/s10661-017-6180-3

EPA, 2010. Fluoride: Exposure and Relative Source Contribution Analysis. Washington, D.C.

Fawell, J., Bailey, K., Chilton, J., Dahi, E., Fewtrell, L., Magara, Y., 2006. Fluoride in Drinkingwater, World Health Organization. https://doi.org/10.1007/BF01783490

Freire, I.R., Pessan, J.P., Amaral, J.G., Martinhon, C.C.R., Cunha, R.F., Delbem, A.C.B., 2016. Anticaries effect of low-fluoride dentifrices with phosphates in children: A randomized, controlled trial. J. Dent. 50, 37-42. https://doi.org/10.1016/j.jdent.2016.04.013

Giridharan, L., Venugopal, T., Jayaprakash, M., 2009. Assessment of water quality using chemometric tools: A case study of river cooum, South India. Arch. Environ. Contam. Toxicol. 56, 654-669. https://doi.org/10.1007/s00244-009-9310-2

Guissouma, W., Hakami, O., Al-Rajab, A.J., Tarhouni, J., 2017. Risk assessment of fluoride exposure in drinking water of Tunisia. Chemosphere 177, 102-108. https://doi.org/10.1016/j.chemosphere.2017.03.011

Guo, H., Zhang, Y., Xing, L., Jia, Y., 2012. Spatial variation in arsenic and fluoride concentrations of shallow groundwater from the town of Shahai in the Hetao basin, Inner Mongolia. Appl. Geochemistry 27, 2187-2196. https://doi.org/10.1016/j.apgeochem.2012.01.016

Irigoyen-Camacho, M.E., García Pérez, A., Mejía González, A., Huizar Alvarez, R., 2016. Nutritional status and dental fluorosis among schoolchildren in communities with different 
drinking water fluoride concentrations in a central region in Mexico. Sci. Total Environ. 541, 512-519. https://doi.org/10.1016/j.scitotenv.2015.09.085

Izquierdo-Vega, J.A., Sánchez-Gutiérrez, M., Del Razo, L.M., 2008. Decreased in vitro fertility in male rats exposed to fluoride-induced oxidative stress damage and mitochondrial transmembrane potential loss. Toxicol. Appl. Pharmacol. 230, 352-357. https://doi.org/10.1016/j.taap.2008.03.008

Jha, S.K., Mishra, V.K., Sharma, D.K., Damodaran, T., 2011. Fluoride in the environment and its metabolism in humans. Rev. Environ. Contam. Toxicol. 211, 121-142. https://doi.org/10.1007/978-1-4419-8011-3_4

John-Dewole, O.., 2012. Adverse Effects of Inadequate Water Supply on Human Health : a case study of Kajola Local Government in Oyo State , Nigeria By. Greener J. Med. Sci. 2, 115119.

Kaoud, H., Kalifa, B., 2010. Effect of fluoride, cadmium and arsenic intoxication on brain and learning-memory ability in rats. Toxicol. Lett. 196, S53. https://doi.org/10.1016/j.toxlet.2010.03.212

Krivoruchko, K., 2011. Spatial Statistical Data Analysis for GIS Users Spatial Statistical Data Analysis for GIS Users, Esri Press, Rehlands, CA. Esri Press, Rehlands, CA.

Levy, M., Leclerc, B.S., 2012. Fluoride in drinking water and osteosarcoma incidence rates in the continental United States among children and adolescents. Cancer Epidemiol. 36, 83-88. https://doi.org/10.1016/j.canep.2011.11.008

Li, P., Qian, H., Wu, J., Zhang, Y., Zhang, H., 2013. Major Ion Chemistry of Shallow Groundwater in the Dongsheng Coalfield, Ordos Basin, China. Mine Water Environ. 32, 195-206. https://doi.org/10.1007/s10230-013-0234-8

Liu, H., Gao, Y., Sun, L., Li, M., Li, B., Sun, D., 2014. Assessment of relationship on excess fluoride intake from drinking water and carotid atherosclerosis development in adults in fluoride endemic areas, China. Int. J. Hyg. Environ. Health 217, 413-420. https://doi.org/10.1016/j.ijheh.2013.08.001

Magesh, N.S., Chandrasekar, N., Elango, L., 2017. Trace element concentrations in the groundwater of the Tamiraparani river basin, South India: Insights from human health risk and multivariate statistical techniques. Chemosphere 185, 468-479. https://doi.org/10.1016/j.chemosphere.2017.07.044

Maguire, A., 2014. ADA clinical recommendations on topical fluoride for caries prevention. Evid. Based. Dent. https://doi.org/10.1038/sj.ebd.6401019

McGrady, M.G., Ellwood, R.P., Srisilapanan, P., Korwanich, N., Worthington, H. V., Pretty, I.A., 2012. Dental fluorosis in populations from Chiang Mai, Thailand with different fluoride exposures - Paper 1: assessing fluorosis risk, predictors of fluorosis and the potential role of food preparation. BMC Oral Health 12, 1. https://doi.org/10.1186/1472-6831-12-16

Namkaew, M., Wiwatanadate, P., 2012. Association of fluoride in water for consumption and chronic pain of body parts in residents of San Kamphaeng district, Chiang Mai, Thailand. Trop. Med. Int. Heal. 17, 1171-1176. https://doi.org/10.1111/j.1365-3156.2012.03061.x 
National Academy of Science, 2006. Fluoride in Drinking Water: A Scientific Review of EPA's Standards. The National Academies Press. Washington, D.C. https://doi.org/10.17226/11571

National Population Commission, 2010. Population Distribution by Sex,State,LGA\&Senatorial District, 2006 Population and Housing Cencus.

Odjegba, E., Idowu, O., Ikenweiwe, N., Martins, O., Sadeeq, A., 2015. Public Perception of Potable Water Supply in Abeokuta. J. Appl. Sci. Environ. Manag. 19, 5-9.

Odjegba, E.E., Idowu, O.A., Oluwasanya, G.O., Ikenweiwe, N.B., Martins, O., 2014. Assessment of Water Demand and Seasonal Variation of Bacteriological Content of Public Water Systems in Abeokuta ... Int. J. Inst. Ecol. Environ. Stud. 2, 81-92.

Oke, S.A., Tijani, M.N., 2012. Impact of chemical weathering on groundwater chemistry of Abeokuta area ,. Elixir Pollut. 46, 8498-8503.

Rafique, T., Naseem, S., Ozsvath, D., Hussain, R., Bhanger, M.I., Usmani, T.H., 2015. Geochemical controls of high fluoride groundwater in Umarkot Sub-District, Thar Desert, Pakistan. Sci. Total Environ. 271-278. https://doi.org/10.1016/j.scitotenv.2015.05.038

Rafique, T., Naseem, S., Usmani, T.H., Bashir, E., Khan, F.A., Bhanger, M.I., 2009. Geochemical factors controlling the occurrence of high fluoride groundwater in the Nagar Parkar area, Sindh, Pakistan. J. Hazard. Mater. 171, 424-430. https://doi.org/10.1016/j.jhazmat.2009.06.018

Rahaman, M.., 1976. Review of the basement geology of South-Western Nigeria. In: C.A. Kogbe (Ed.) Geology of Nigeria. Elizabethan Publishing Co;, Lagos, Nigeria.

Rasool, A., Xiao, T., Farooqi, A., Shafeeque, M., Masood, S., Ali, S., Fahad, S., Nasim, W., 2016. Arsenic and heavy metal contaminations in the tube well water of Punjab, Pakistan and risk assessment: A case study. Ecol. Eng. 95, 90-100. https://doi.org/10.1016/j.ecoleng.2016.06.034

Ravikumar, P., Somashekar, R.K., 2017. Principal component analysis and hydrochemical facies characterization to evaluate groundwater quality in Varahi river basin, Karnataka state, India. Appl. Water Sci. 7, 745-755. https://doi.org/10.1007/s13201-015-0287-X

Salifu, A., Petrusevski, B., Ghebremichael, K., Buamah, R., Amy, G., 2012. Multivariate statistical analysis for fluoride occurrence in groundwater in the Northern region of Ghana. J. Contam. Hydrol. 140-141, 34-44. https://doi.org/10.1016/j.jconhyd.2012.08.002

Samsonova, V.P., Blagoveshchenskii, Y.N., Meshalkina, Y.L., 2017. Use of empirical Bayesian kriging for revealing heterogeneities in the distribution of organic carbon on agricultural lands. Eurasian Soil Sci. 50, 305-311. https://doi.org/10.1134/S1064229317030103

Saxena, V.K., Ahmed, S., 2001. Dissolution of fluoride in groundwater: A water-rock interaction study. Environ. Geol. 40, 1084-1087. https://doi.org/10.1007/s002540100290

Shen, J., Schäfer, A.I., 2015. Factors affecting fluoride and natural organic matter (NOM) removal from natural waters in Tanzania by nanofiltration/reverse osmosis. Sci. Total Environ. 527528, 520-529. https://doi.org/10.1016/j.scitotenv.2015.04.037 
Shivaprakash, P.K., Ohri, K., Noorani, H., 2011. Relation between dental fluorosis and intelligence quotient in school children of Bagalkot district. J. Indian Soc. Pedod. Prev. Dent. 29, 117120. https://doi.org/10.4103/0970-4388.84683

Singh, C.K., Kumari, R., Singh, N., Mallick, J., Mukherjee, S., 2013. Fluoride enrichment in aquifers of the Thar desert: Controlling factors and its geochemical modelling. Hydrol. Process. 27, 2462-2474. https://doi.org/10.1002/hyp.9247

Singh, C.K., Mukherjee, S., 2015. Aqueous geochemistry of fluoride enriched groundwater in arid part of Western India. Environ. Sci. Pollut. Res. 22, 2668-2678. https://doi.org/10.1007/s11356-014-3504-5

Smedley, P., Nkotagu, H., Pelig-Ba, K., MacDonald, A., Tyler-Whittle, R., Whitehead, E., Kinniburgh, D., 2002. Fluoride in groundwater from high-fluoride areas in Ghana and Tanzania. "Minimising fluoride in drinking water in problem aquifers." Br. Geol. Surv. Comm. Report, CR/02/316 77.

Subba Rao, N., 1993. Environmental impact of industrial effluents in groundwater regions of Visakhapatnam Industrial Complex. Indian J. Geol. 65, 35-43.

Subba Rao, N., Subrahmanyam, A., Babu Rao, G., 2013. Fluoride-bearing groundwater in Gummanampadu Sub-basin, Guntur District, Andhra Pradesh, India. Environ. Earth Sci. 70, 575-586. https://doi.org/10.1007/s12665-012-2142-9

Sun, L., Gao, Y., Liu, H., Zhang, W., Ding, Y., Li, B., Li, M., Sun, D., 2013. An assessment of the relationship between excess fluoride intake from drinking water and essential hypertension in adults residing in fluoride endemic areas. Sci. Total Environ. 443, 864-869. https://doi.org/10.1016/j.scitotenv.2012.11.021

Tenebe, I.T., Emenike, C.P., Ogbiye, A.S., Ngene, B.U., Omeje, M., Olatunji, O.O., 2018. A laboratory assessment of the effect of varying roughness on dissolved oxygen using error correction method. Cogent Eng. 0, 1-11. https://doi.org/10.1080/23311916.2018.1427191

Tenebe, I.T., Ogbiye, A., Omole, D.O., Emenike, P.C., 2016. Estimation of longitudinal dispersion co-efficient: A review. Cogent Eng. 3. https://doi.org/10.1080/23311916.2016.1216244

Tenebe, I.T., Ogbiye, A.S., Omole, D.O., Emenike, P.C., 2017. Modelling and sensitivity analysis of varying roughness effect on dispersion coefficient: a laboratory study 21298, 1-7. https://doi.org/10.5004/dwt.2017.21298

Tirkey, P., Bhattacharya, T., Chakraborty, S., Baraik, S., 2017. Assessment of groundwater quality and associated health risks: A case study of Ranchi city, Jharkhand, India. Groundw. Sustain. Dev. 5, 85-100. https://doi.org/10.1016/j.gsd.2017.05.002

Ufoegbune, G.., Lamidi, K.., Awomeso, J.., Eruola, A.., Idowu, O.., 2009. Hydro-geological characteristics and groundwater quality assessment in some selected communities of Abeokuta, Southwest Nigeria. J. Environ. Chem. Ecotoxicol. 1, 010-022.

US EPA, 2011. Exposure Factors Handbook: 2011 Edition, 2011 Editi. ed, U.S. Environmental Protection Agency. https://doi.org/EPA/600/R-090/052F

US EPA, 1989. Risk Assessment Guidance for Superfund Volume I Human Health Evaluation 
Manual (Part A), US EPA. https://doi.org/EPA/540/1-89/002

661

662

663

664

665

666

667

668

669

670

671

672

673

674

675

676

677

678

679

680

681

682

683

684

685

686

687

688

689

690

691

692
Varol, E., Akcay, S., Ersoy, I.H., Ozaydin, M., Koroglu, B.K., Varol, S., 2010. Aortic elasticity is impaired in patients with endemic fluorosis. Biol. Trace Elem. Res. 133, 121-127. https://doi.org/10.1007/s12011-009-8578-4

Viswanathan, G., Jaswanth, A., Gopalakrishnan, S., Siva ilango, S., Aditya, G., 2009. Determining the optimal fluoride concentration in drinking water for fluoride endemic regions in South India. Sci. Total Environ. 407, 5298-5307. https://doi.org/10.1016/j.scitotenv.2009.06.028

Walia, T., Abu Fanas, S., Akbar, M., Eddin, J., Adnan, M., 2017. Estimation of fluoride concentration in drinking water and common beverages in United Arab Emirates (UAE). Saudi Dent. J. 29, 117-122. https://doi.org/10.1016/j.sdentj.2017.04.002

Wayland, K.G., Long, D.T., Hyndman, D.W., Pijanowski, B.C., Woodhams, S.M., Haack, S.K., 2003. with Synoptic Sampling and R-Mode Factor Analysis. J. Environ. Qual. 32, 180-190.

WHO, 2011. WHO Guidelines for Drinking-water Quality., 4th Editio. ed, World Health Organization. https://doi.org/10.1016/S1462-0758(00)00006-6

Xiao, J., Jin, Z., Zhang, F., 2015. Geochemical controls on fluoride concentrations in natural waters from the middle Loess Plateau, China. J. Geochemical Explor. 159, 252-261. https://doi.org/10.1016/j.gexplo.2015.09.018

Yang, M., Fei, Y., Ju, Y., Ma, Z., Li, H., 2012. Health risk assessment of groundwater pollutionA case study of typical city in North China plain. J. Earth Sci. 23, 335-348. https://doi.org/10.1007/s12583-012-0260-7

Yousefi, M., Ghoochani, M., Hossein Mahvi, A., 2018. Health risk assessment to fluoride in drinking water of rural residents living in the Poldasht city, Northwest of Iran. Ecotoxicol. Environ. Saf. 148, 426-430. https://doi.org/10.1016/j.ecoenv.2017.10.057

Zhai, Y., Zhao, X., Teng, Y., Li, X., Zhang, J., Wu, J., Zuo, R., 2017. Groundwater nitrate pollution and human health risk assessment by using HHRA model in an agricultural area, NE China. Ecotoxicol. Environ. Saf. 137, 130-142. https://doi.org/10.1016/j.ecoenv.2016.11.010

Zhang, L., Huang, D., Yang, J., Wei, X., Qin, J., Ou, S., Zhang, Z., Zou, Y., 2017. Probabilistic risk assessment of Chinese residents' exposure to fluoride in improved drinking water in endemic fluorosis areas. Environ. Pollut. 222, 118-125. https://doi.org/10.1016/j.envpol.2016.12.074 
Table 1: Prediction error information obtained from the empirical Bayesian kriging (EBK) model

\begin{tabular}{l|ccccccccccccccccc}
\hline & $\mathrm{pH}$ & $\mathrm{TDS}$ & $\mathrm{EC}$ & $\mathrm{F}^{-}$ & $\mathrm{Fe}^{2+}$ & $\mathrm{Mn}$ & $\mathrm{Ca}^{2+}$ & $\mathrm{K}+$ & $\mathrm{Mg}^{2+}$ & $\mathrm{Na}^{+}$ & $\mathrm{SO}_{4}^{2-}$ & $\mathrm{SiO}_{2}$ & $\mathrm{HCO}_{3}{ }^{-}$ & $\mathrm{Cl}^{-}$ & $\mathrm{NO}_{3}{ }^{-}$ & $\mathrm{CO}_{3}{ }^{2-}$ \\
\hline Mean & 0.104 & 0.832 & 12.048 & 0.004 & 0.007 & 0.002 & 0.746 & 0.086 & -4.519 & 1.348 & 3.378 & -0.162 & 3.550 & 3.727 & 0.111 & 0.229 \\
RMS Pred. & 0.391 & 451.368 & 679.930 & 0.406 & 0.707 & 0.023 & 40.291 & 2.114 & 85.810 & 104.470 & 192.912 & 2.009 & 110.187 & 135.657 & 1.859 & 7.985 \\
MS & 0.022 & 0.005 & 0.022 & 0.009 & 0.019 & 0.092 & 0.017 & 0.041 & -0.054 & 0.009 & 0.015 & -0.072 & 0.030 & 0.021 & 0.555 & 0.029 \\
RMSS & 0.968 & 0.967 & 0.966 & 0.979 & 0.999 & 0.998 & 0.966 & 0.993 & 0.970 & 0.975 & 0.910 & 0.981 & 0.986 & 0.972 & 0.959 & 0.968 \\
ASE & 0.402 & 464.203 & 716.913 & 0.416 & 0.697 & 0.023 & 41.830 & 2.128 & 88.373 & 107.705 & 215.608 & 2.037 & 109.195 & 141.679 & 1.970 & 8.276 \\
\hline
\end{tabular}


Table 2: Hazard quotients via ingestion pathway (HQ $\left.\mathbf{H}_{\mathbf{I N}}\right)$ for different age classification

\begin{tabular}{|c|c|c|c|c|c|c|c|}
\hline \multicolumn{8}{|c|}{ HQIN VALUES } \\
\hline REGION & (6 - 12months) & (6 - 11years) & (11 - 16years) & (16 - 18years) & (18 - 21years) & ( $\geq 21$ years) & (> 65years) \\
\hline R1 & $* 1.877$ & 0.770 & 0.574 & 0.450 & 0.591 & 0.637 & 0.583 \\
\hline $\mathbf{R} 2$ & $* 2.405$ & $* * 0.986$ & 0.735 & 0.576 & 0.758 & 0.817 & 0.747 \\
\hline R3 & $* 2.833$ & *1.161 & 0.866 & 0.679 & 0.892 & $* * 0.962$ & 0.880 \\
\hline R4 & *3.016 & *1.236 & 0.922 & 0.723 & $* * 0.950$ & *1.024 & 0.937 \\
\hline R5 & *2.021 & 0.828 & 0.617 & 0.484 & 0.637 & 0.686 & 0.628 \\
\hline R6 & *2.906 & *1.191 & 0.888 & 0.696 & 0.915 & *0.987 & 0.902 \\
\hline R7 & $* 2.369$ & $* * 0.971$ & 0.724 & 0.568 & 0.746 & 0.804 & 0.736 \\
\hline $\mathbf{R 8}$ & *1.215 & 0.498 & 0.371 & 0.291 & 0.383 & 0.412 & 0.377 \\
\hline R9 & 0.913 & 0.374 & 0.279 & 0.219 & 0.288 & 0.310 & 0.283 \\
\hline R10 & $* 2.650$ & *1.086 & 0.810 & 0.635 & 0.835 & 0.900 & 0.823 \\
\hline R11 & $* 1.484$ & 0.608 & 0.453 & 0.355 & 0.467 & 0.504 & 0.461 \\
\hline R12 & 0.910 & 0.373 & 0.278 & 0.218 & 0.287 & 0.309 & 0.282 \\
\hline R13 & $* 2.473$ & *1.014 & 0.756 & 0.592 & 0.779 & 0.839 & 0.768 \\
\hline R14 & $* 2.259$ & 0.926 & 0.690 & 0.541 & 0.712 & 0.767 & 0.701 \\
\hline R15 & *3.034 & *1.244 & 0.927 & 0.727 & $* * 0.956$ & *1.030 & 0.942 \\
\hline R16 & *3.364 & *1.379 & *1.028 & 0.806 & $* 1.060$ & *1.142 & *1.045 \\
\hline R17 & *3.217 & *1.319 & $* * 0.983$ & 0.771 & *1.013 & *1.092 & $* * 0.999$ \\
\hline R18 & $* 2.430$ & $* * 0.996$ & 0.742 & 0.582 & 0.765 & 0.825 & 0.755 \\
\hline R19 & $* 2.295$ & 0.941 & 0.701 & 0.550 & 0.723 & 0.779 & 0.713 \\
\hline R20 & *2.814 & *1.154 & 0.860 & 0.674 & 0.887 & $* * 0.956$ & 0.874 \\
\hline R21 & 0.897 & 0.368 & 0.274 & 0.215 & 0.283 & 0.305 & 0.279 \\
\hline
\end{tabular}

* HQ values exceeding the US EPA and WHO standards

** HQ values exceeding 0.95 
Table 3: Hazard quotients via dermal pathway (HQDE) for different age classification

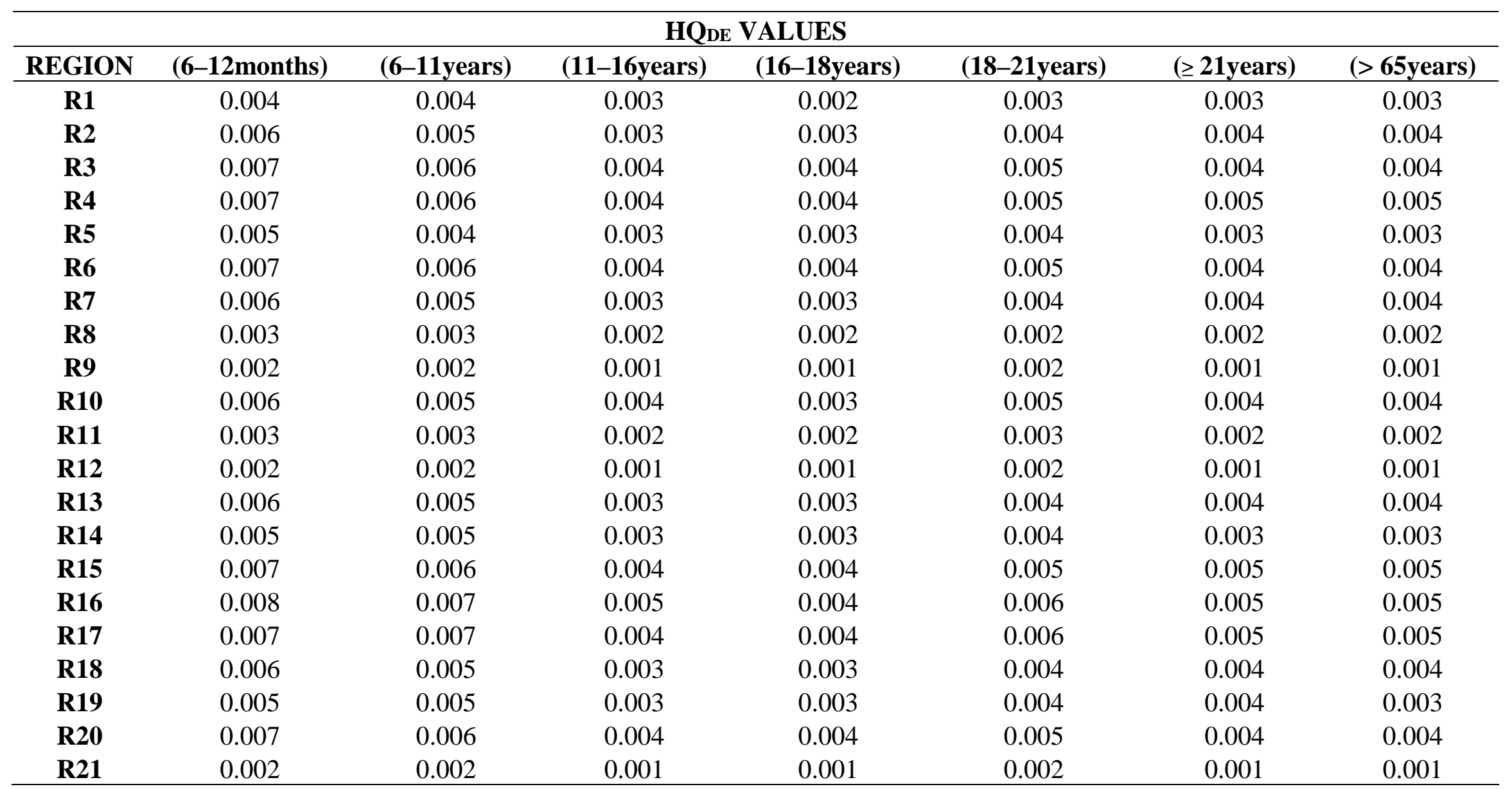




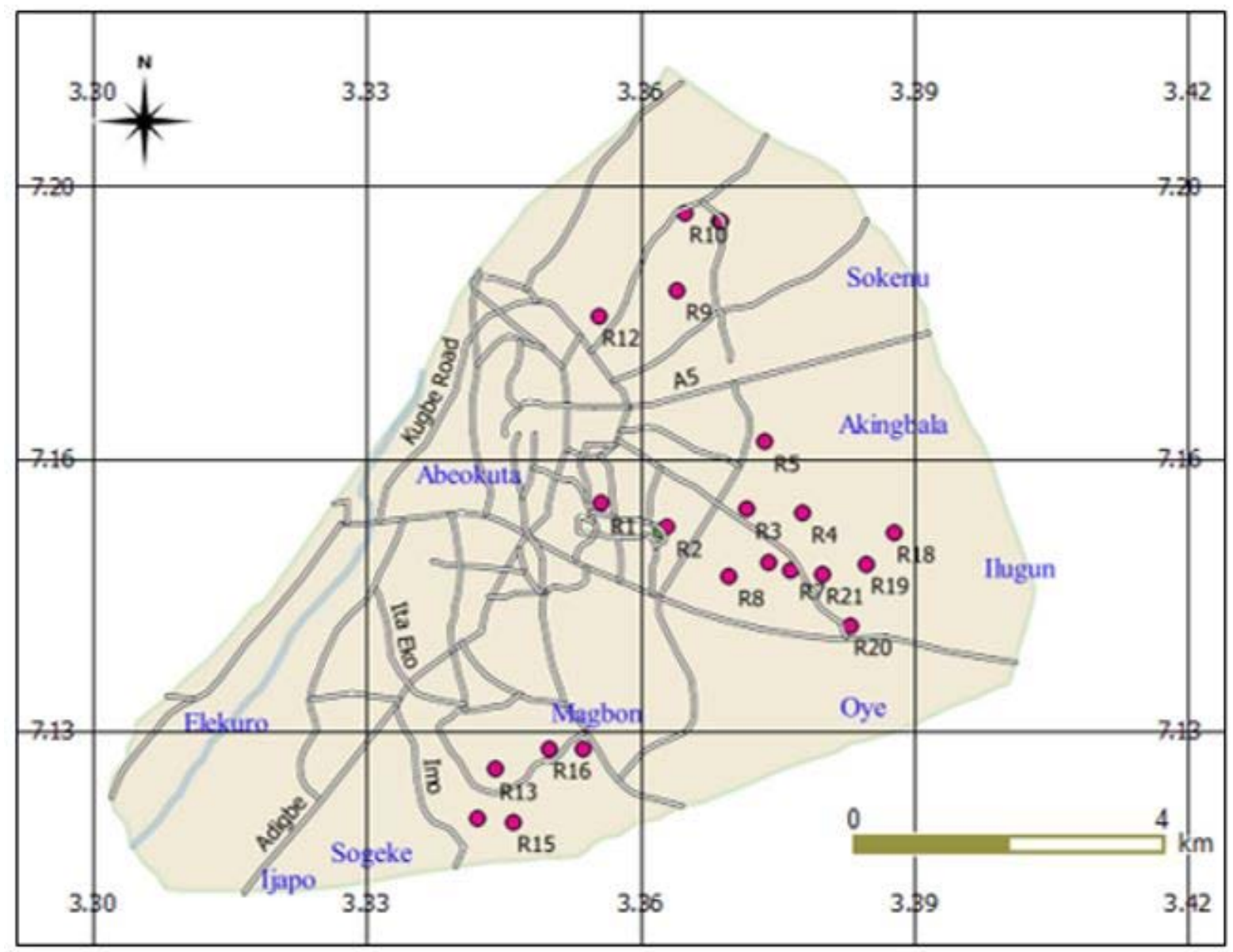

Fig. 1: Map of study area showing sampling locations 


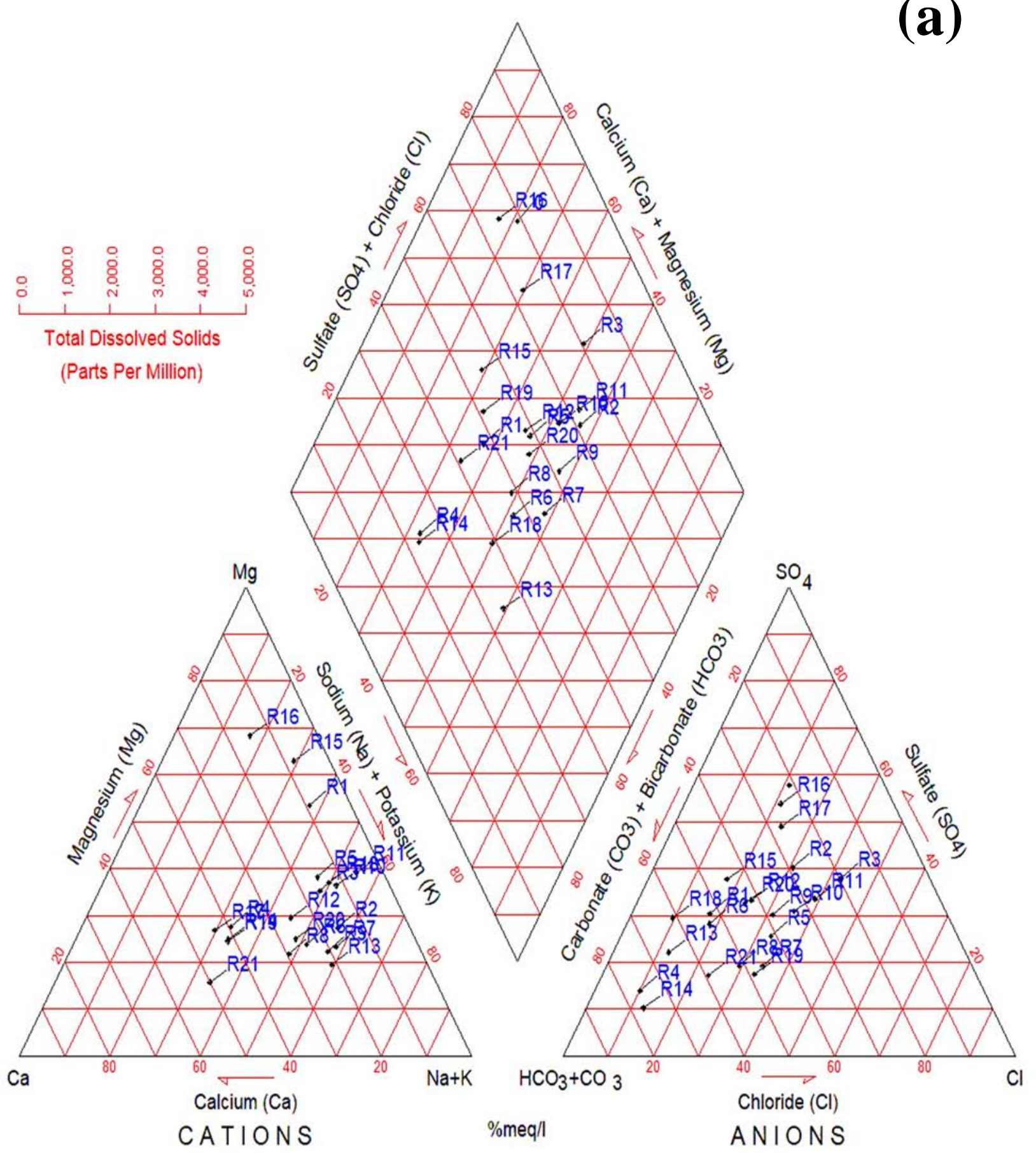



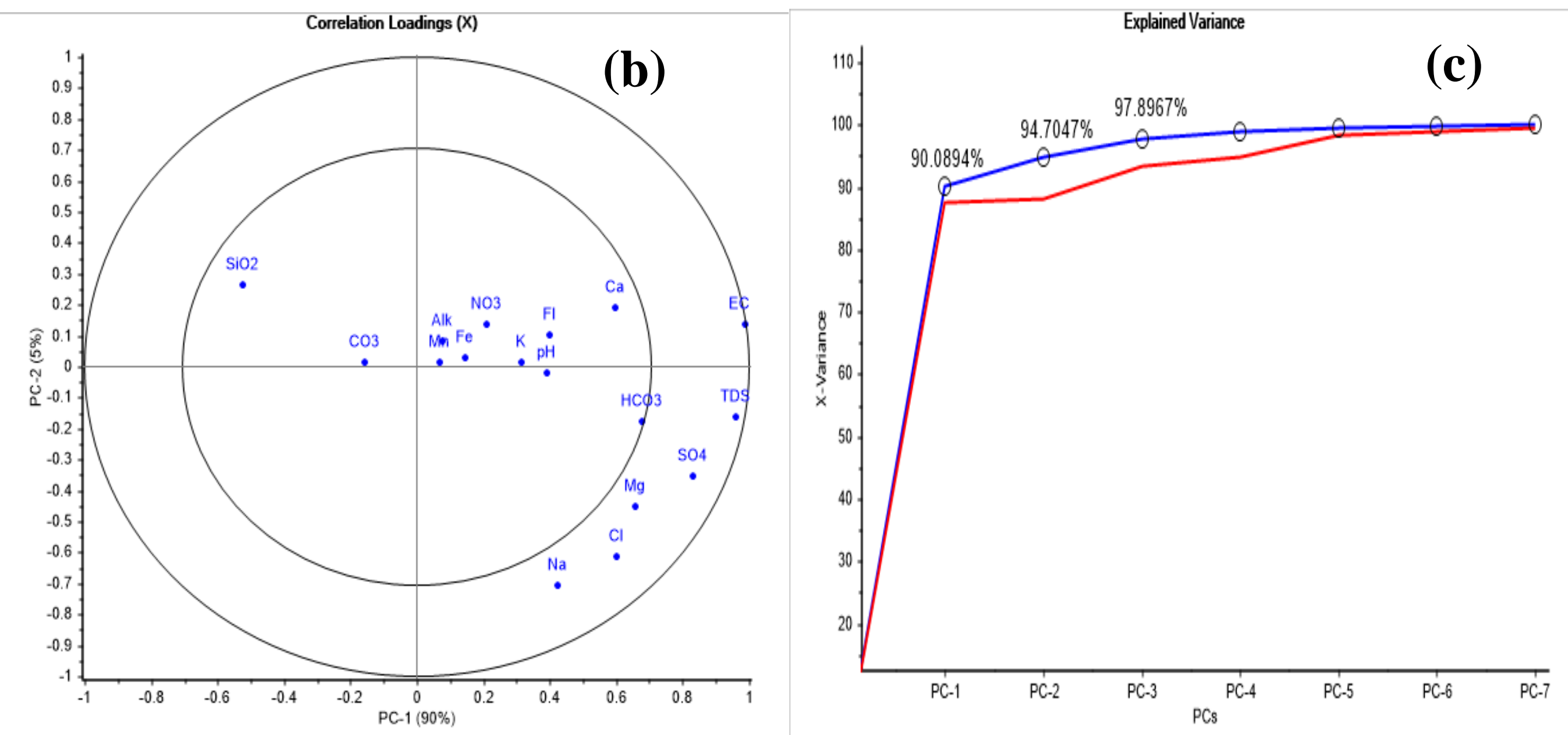

Fig. 2(a-c): (a) Characterization of hydrochemical facies with piper plot (b) PCA plot showing the loadings of each water quality parameter (c) Scree plot showing the percentage contribution of each principal component 

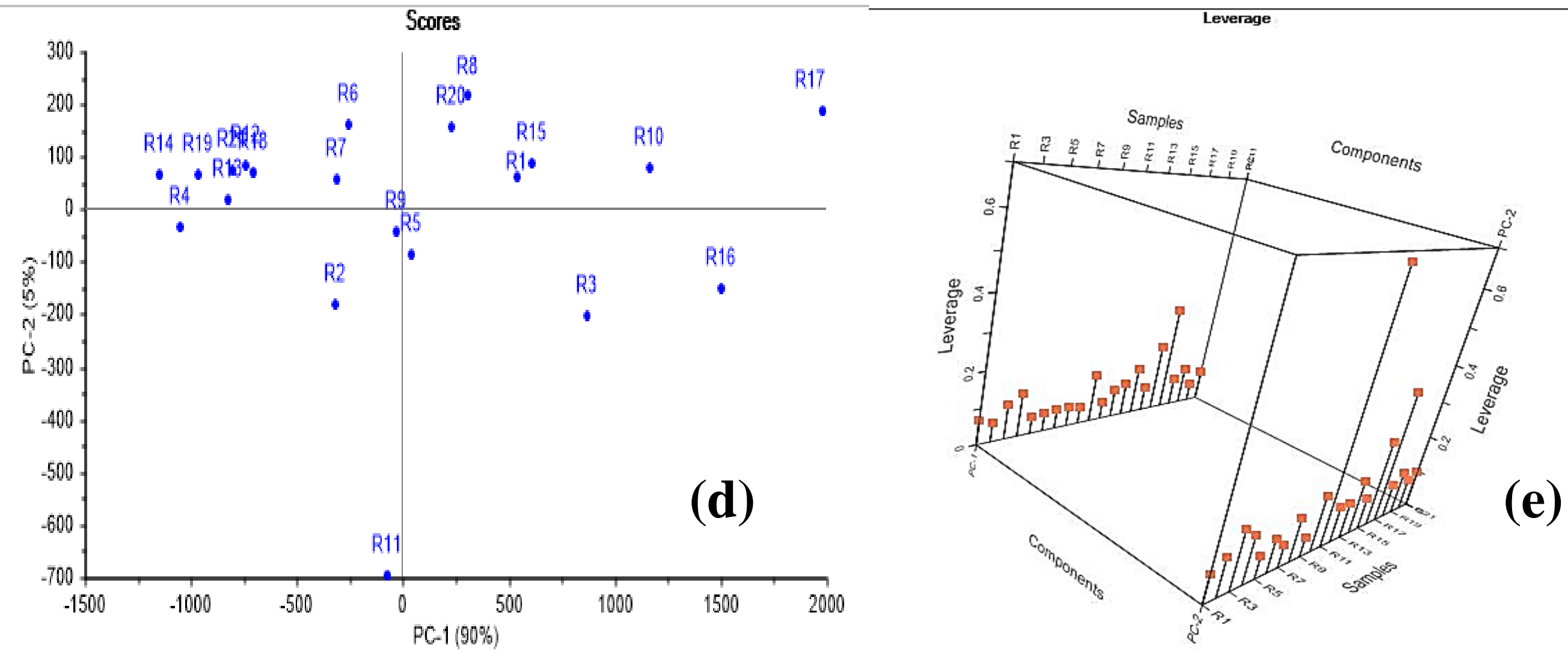

Fig. 2(d-e): (d) Score plot of the water samples (e) Influence plot showing the contribution of the water sample to the principal components 


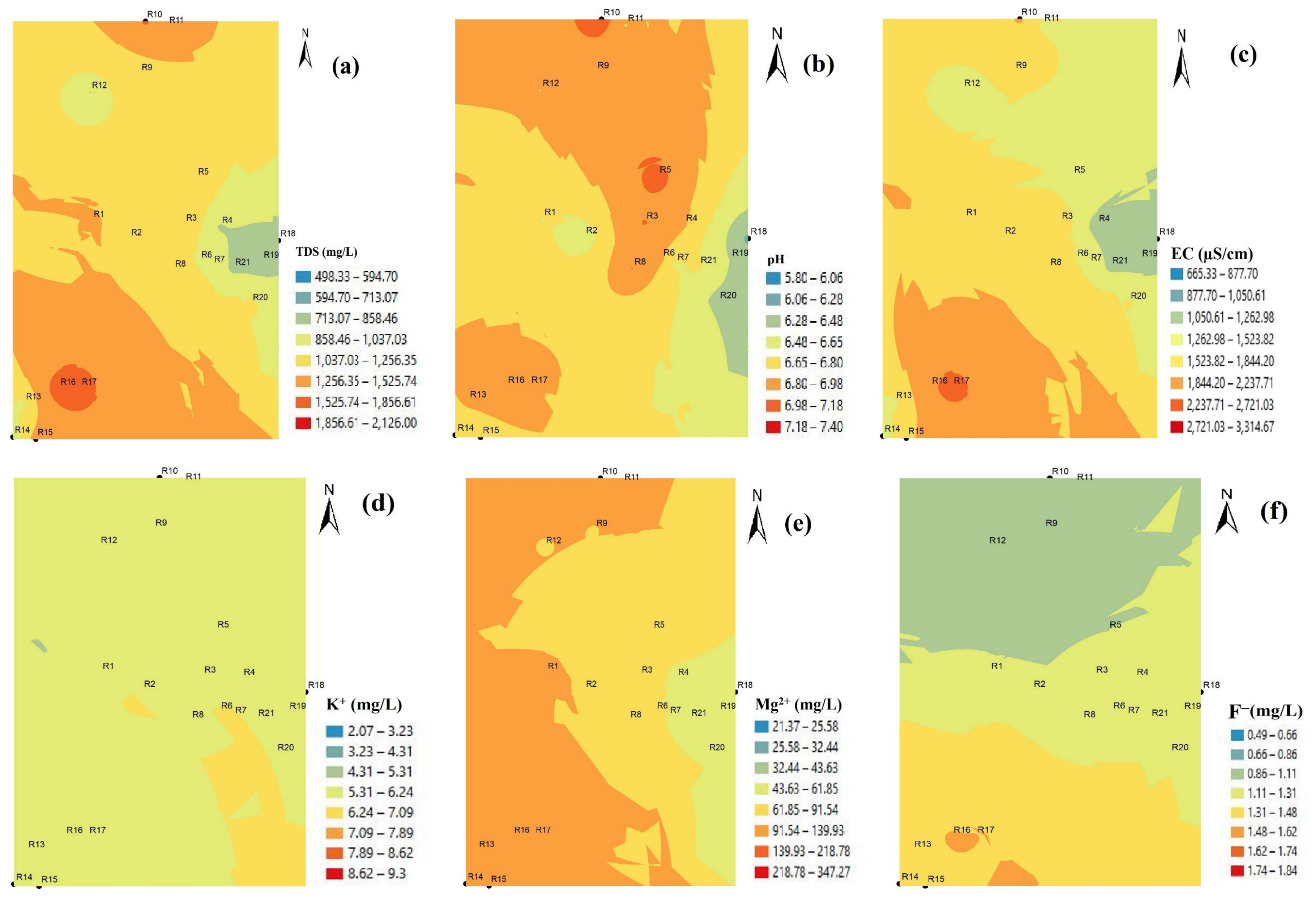




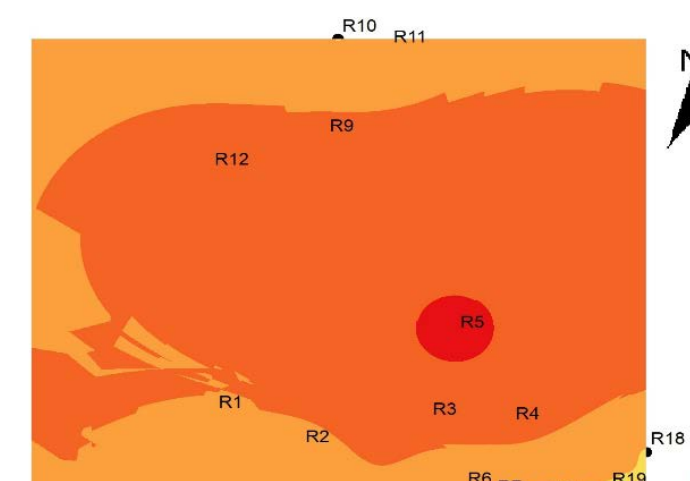

(g)

${ }_{R 8} \quad{ }^{R 6}{ }_{R 7} R_{21} \quad R 19 \quad \mathbf{F e}^{2+}(\mathbf{m g} / \mathbf{L})$

$0.02-0.02$

$0.02-0.04$

$0.04-0.07$

$0.07-0.14$

$0.14-0.30$

$0.30-0.64$

$0.64-1.37$

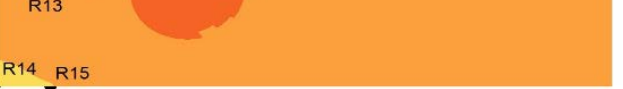

- $1.37-2.96$

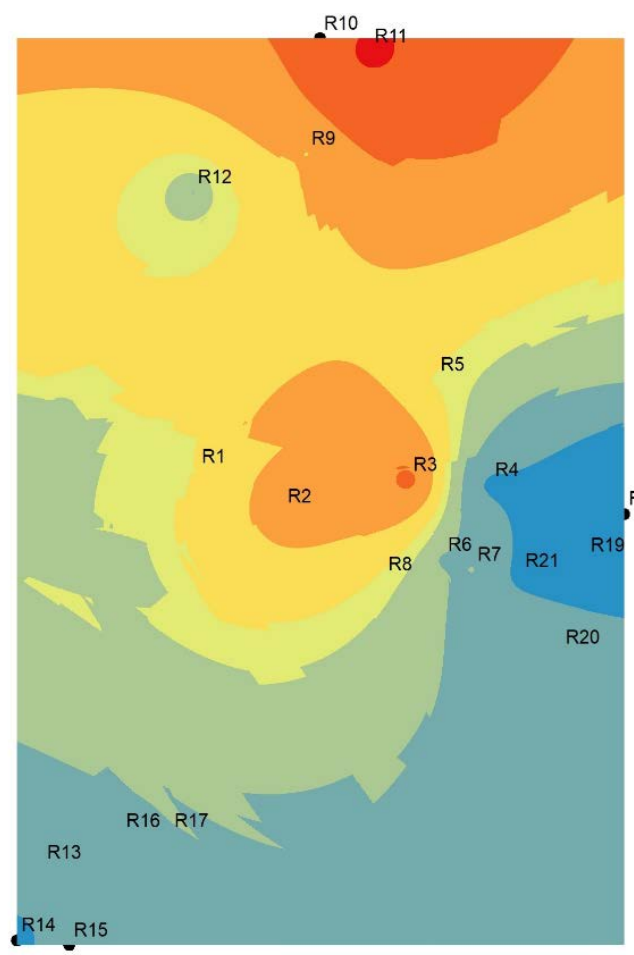

$\bigwedge^{N}(j)$

$\mathrm{Na}^{+}(\mathrm{mg} / \mathrm{L})$

- 55.97-137.36

물 $137.36-179.09$

$179.09-200.48$

$200.48-211.45$

$211.45-232.84$

- $232.84-274.57$

$274.57-355.96$

- $355.96-514.73$

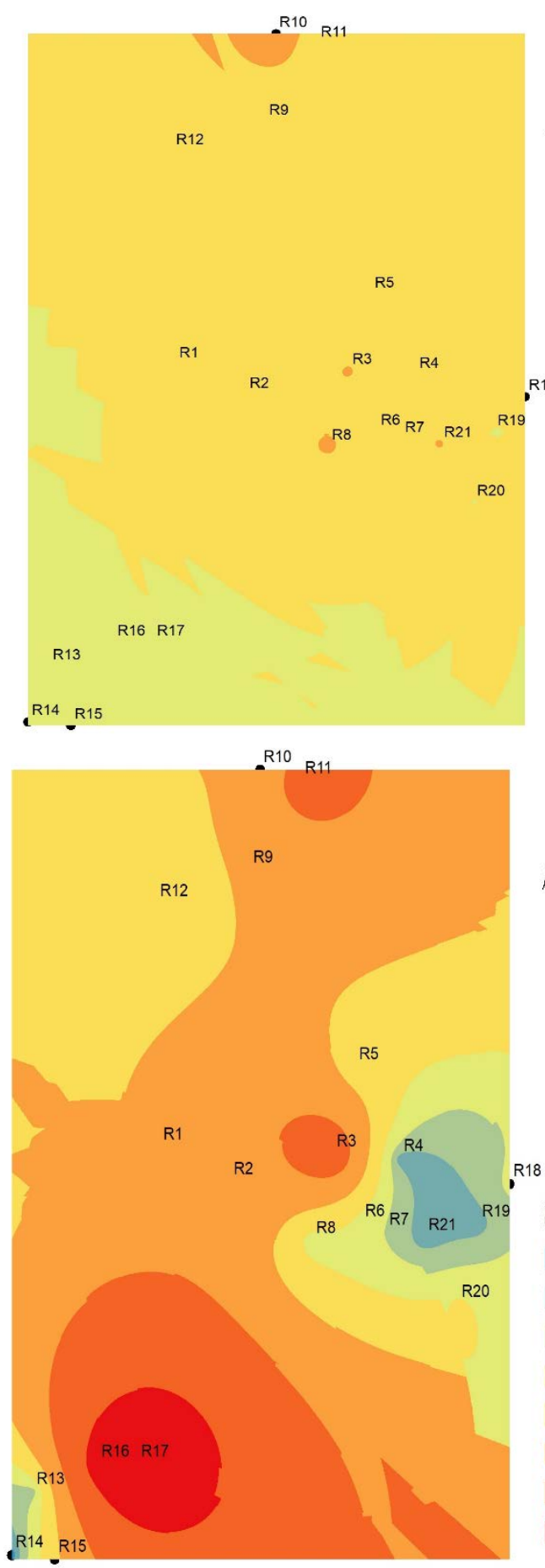

$\stackrel{N}{\Lambda}$

(h)

Mn (mg/L)

- $0.01-0.01$

$0.01-0.02$

$0.02-0.02$

$0.02-0.03$

$0.03-0.04$

- $0.04-0.06$

$0.06-0.07$

0.07-0.08

$\AA^{N}(\mathbf{K})$

$\mathrm{SO}_{4}{ }^{2-}(\mathrm{mg} / \mathrm{L})$

- $35.73-76.95$

$76.95-104.28$

$104.28-145.5$

$145.5-207.68$

- $207.68-301.49$

$301.49-443.02$

$443.02-656.52$

- $656.52-978.6$

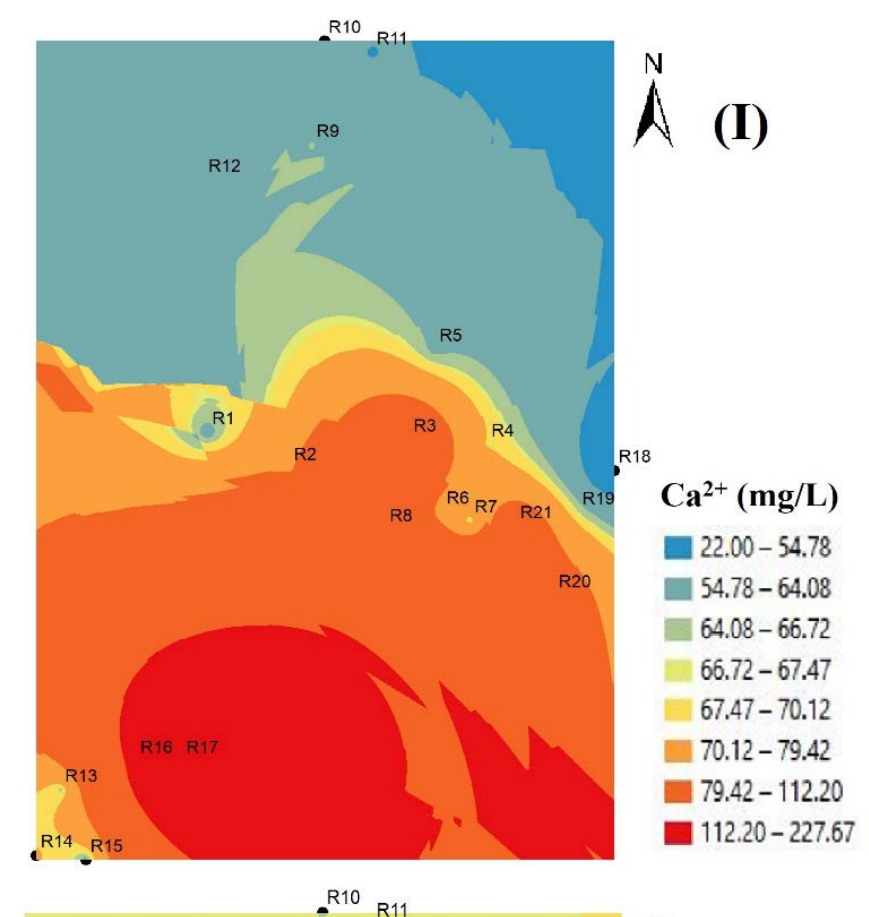

$\bigwedge^{N}(\mathbf{L})$

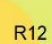

R9

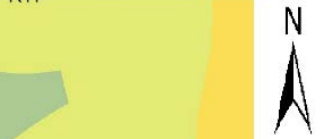

R16 R17

R13

R14 R15
$\mathrm{SiO}_{2}(\mathrm{mg} / \mathrm{L})$

$0.40-1.14$

$1.14-1.79$

$1.79-2.52$

$2.52-3.36$

$3.36-4.31$

$4.31-5.40$

ㄷ. $5.40-6.63$

- $6.63-8.03$ 

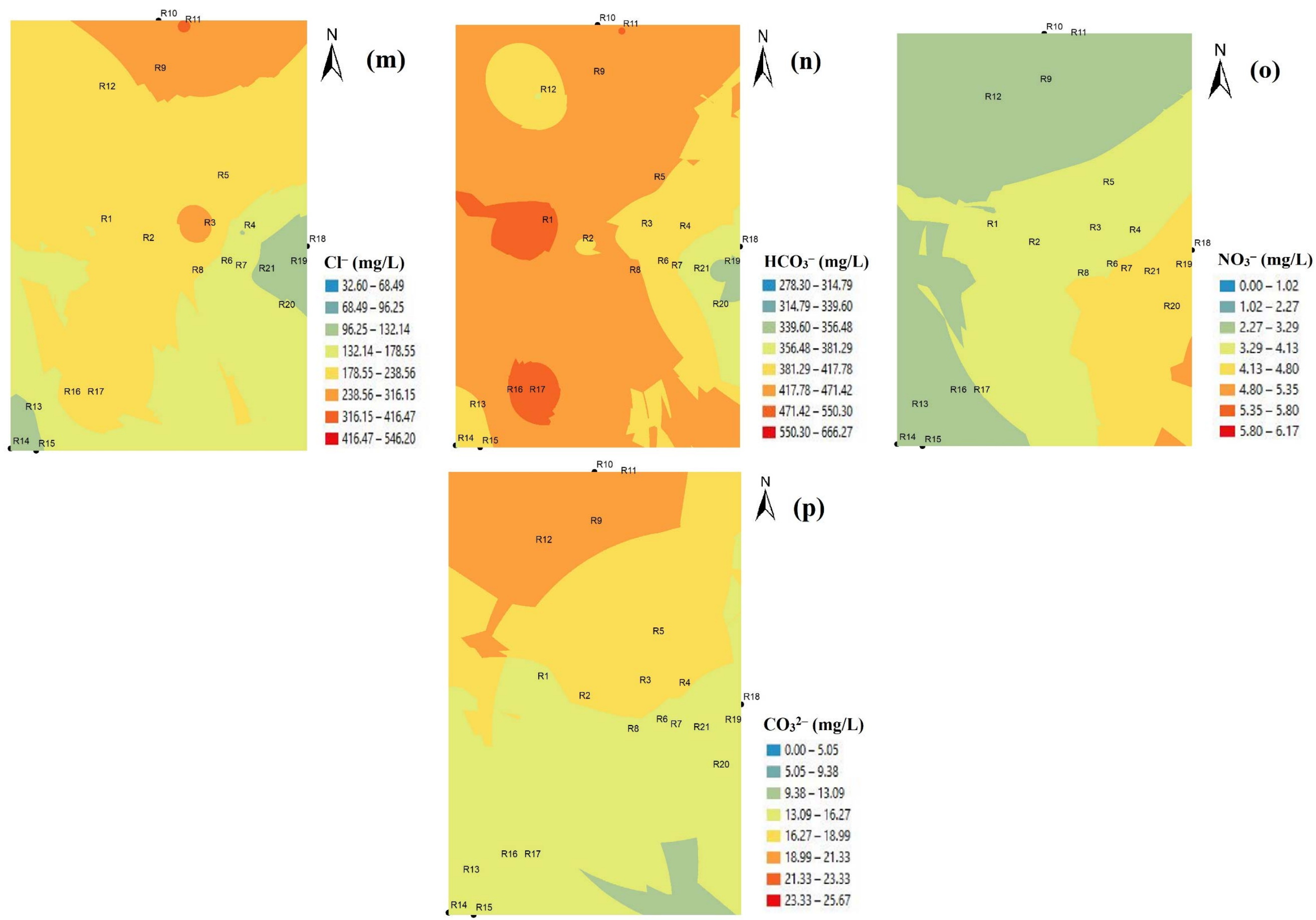

Fig. 3 : Spatial distribution maps of (a) TDS (b) $\mathrm{pH}$ (c) $\mathrm{EC}$ (d) $\mathrm{K}^{+}$(e) $\mathrm{Mg}^{2+}$ (f) $\mathrm{F}^{-}$(g) $\mathrm{Fe}^{2+}$ (h) $\mathrm{Mn}$ (i) $\mathrm{Ca}^{2+}$ (j) $\mathrm{Na}^{+}$(k) $\mathrm{SO}_{4}{ }^{2-}$ (l) $\mathrm{SiO}_{2}$ (m) $\mathrm{Cl}^{-}$(n) $\mathrm{HCO}_{3}{ }^{-}$(o) $\mathrm{NO}_{3}{ }^{-}$(p) $\mathrm{CO}_{3}{ }^{2-}$ in the study area. 

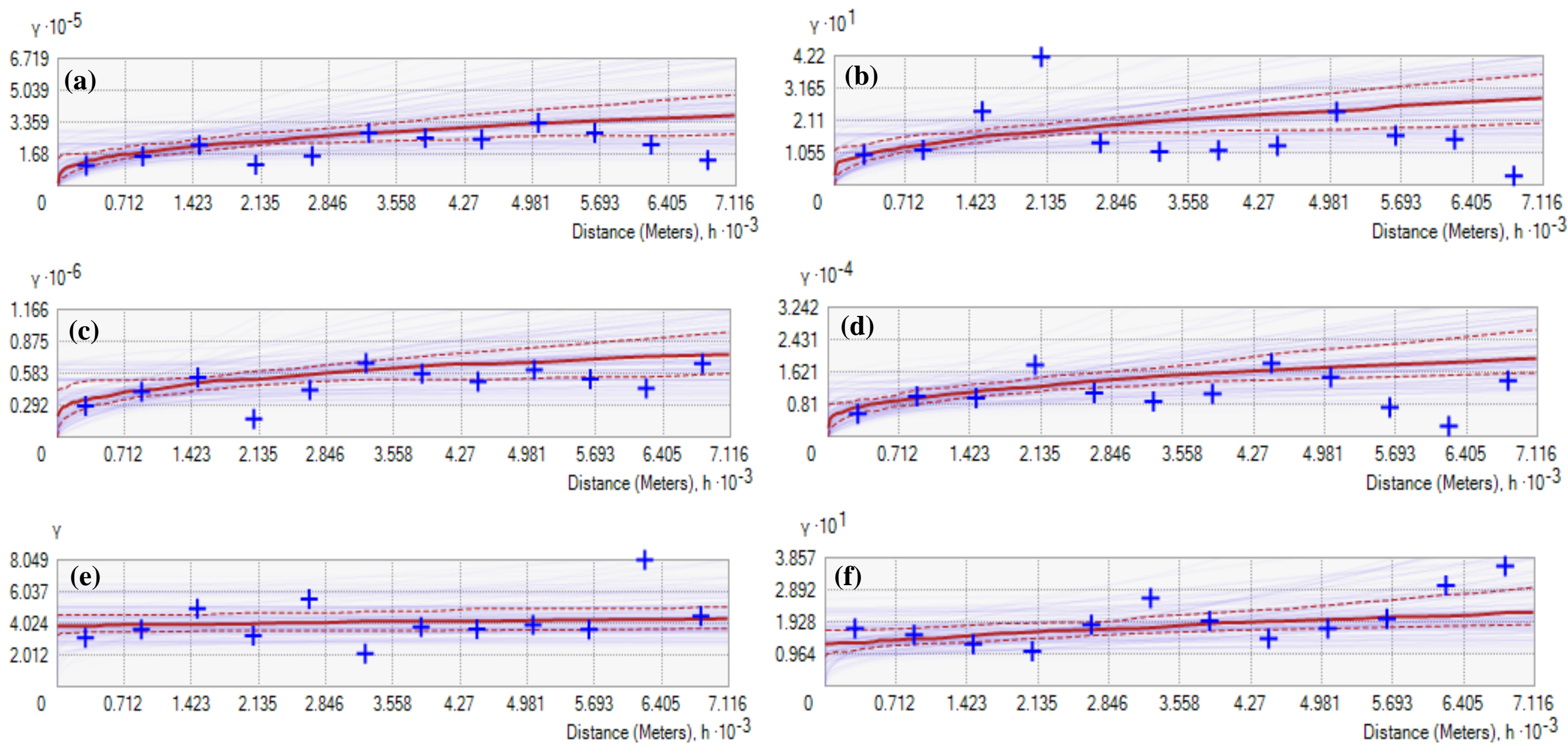

$$
\mathrm{Y} \cdot 10^{1}
$$
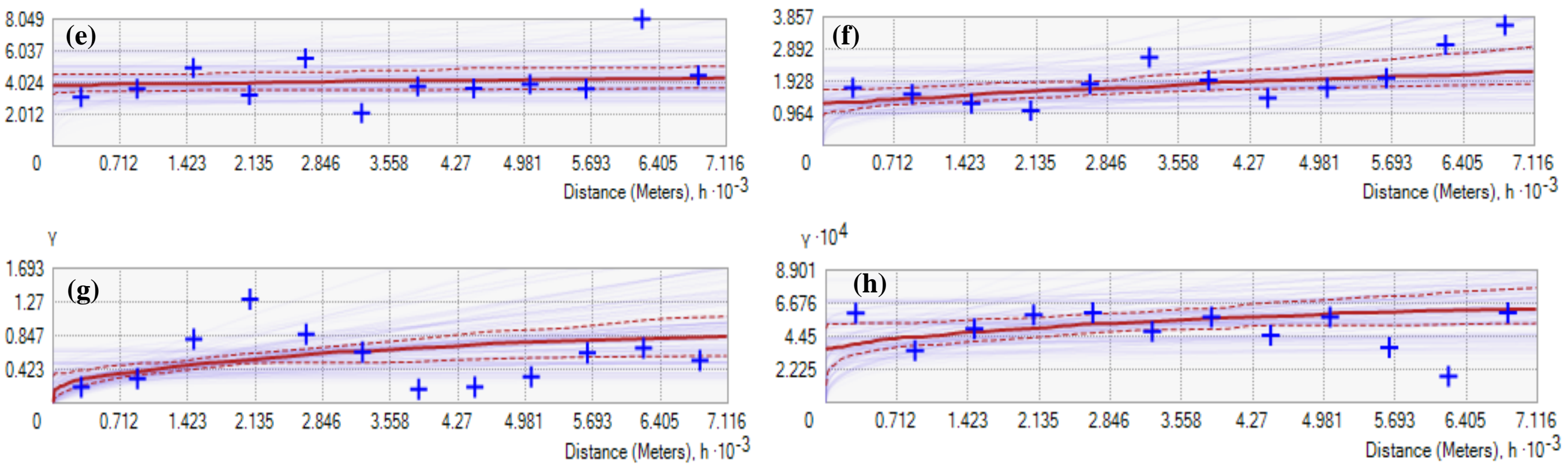

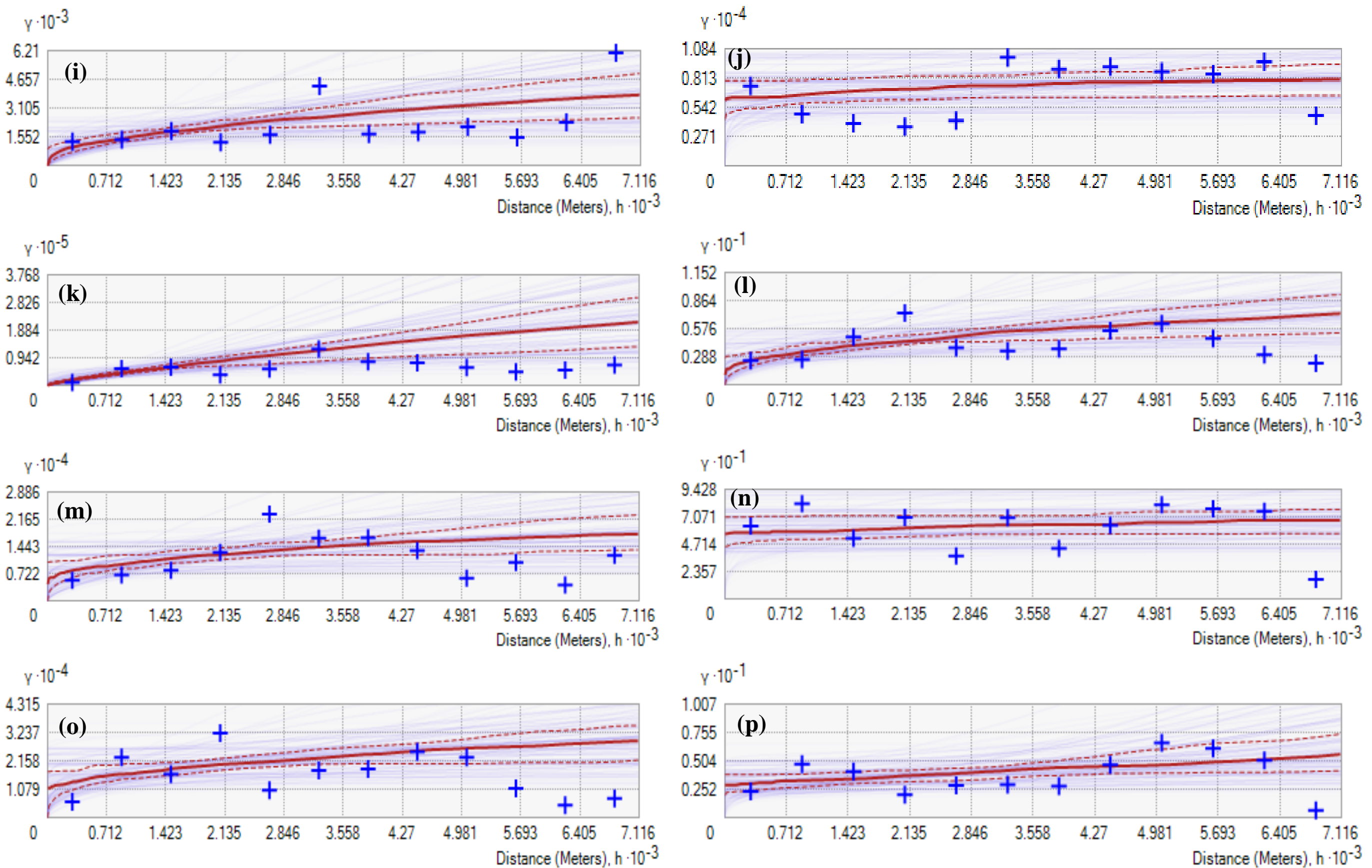

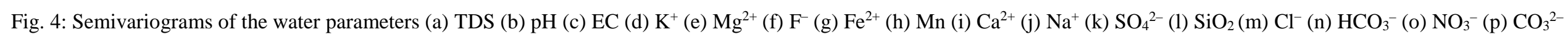




\section{HIGHLIGHTS}

- Water quality was assessed and compared with WHO standards

- Water quality parameters is modelled spatially and statistically

- Contaminant sources were inferred using multivariate statistical technique

- Health risk assessment was computed through ingestion and dermal contact route 